\title{
Prognostic and predictive factors in pancreatic cancer
}

\begin{abstract}
Emanuela Dell'Aquila ${ }^{1}$, Claudia Angela Maria Fulgenzi ${ }^{1}$, Alessandro Minelli ${ }^{1}$, Fabrizio Citarella ${ }^{1}$, Marco Stellatoํㅜㄹ Francesco Pantano ${ }^{1}$, Marco Russano ${ }^{1}$, Maria Concetta Cursano ${ }^{1}$, Andrea Napolitano ${ }^{1}$, Tea Zeppola ${ }^{1}$, Bruno Vincenzi ${ }^{1}$, Giuseppe Tonini ${ }^{1}$ and Daniele Santini ${ }^{1}$

${ }^{1}$ Department of Medical Oncology, University Campus Bio-Medico, Rome 00128, Italy

Correspondence to: Fabrizio Citarella, email: f.citarella@unicampus.it

Keywords: metastatic pancreatic cancer; predictive and prognostic factors; CA 19-9; gemcitabine-abraxane; FOLFIRINOX

Received: January 19, $2020 \quad$ Accepted: February 17, $2020 \quad$ Published: March 10, 2020

Copyright: Dell'Aquila et al. This is an open-access article distributed under the terms of the Creative Commons Attribution License 3.0 (CC BY 3.0), which permits unrestricted use, distribution, and reproduction in any medium, provided the original author and source are credited.
\end{abstract}

\section{ABSTRACT}

Pancreatic cancer is one of the leading causes of cancer death worldwide. Its high mortality rate has remained unchanged for years. Radiotherapy and surgery are considered standard treatments in early and locally advanced stages. Chemotherapy is the only option for metastatic patients. Two treatment regimens, i. e. the association of 5-fluorouracil- irinotecan-oxaliplatin (FOLFIRINOX) and the association of nabpaclitaxel with gemcitabine, have been shown to improve outcomes for metastatic pancreatic adenocarcinoma patients. However, there are not standardized predictive biomarkers able to identify patients who benefit most from treatments. CA19-9 is the most studied prognostic biomarker, its predictive role remains unclear. Other clinical, histological and molecular biomarkers are emerging in prognostic and predictive settings. The aim of this review is to provide an overview of prognostic and predictive markers used in clinical practice and to explore the most promising fields of research in terms of treatment selection and tailored therapy in pancreatic cancer.

\section{INTRODUCTION}

Pancreatic ductal adenocarcinoma (PDAC) is the 12 th most frequent cancer in the world and it is the 4 th cause of cancer-related death in Western Countries, with a mortality rate almost equal to its incidence [1] and a 5 year survival rate of $5-7 \%$ [2]. The vast majority of patients is diagnosed with metastatic or inoperable disease due to the vagueness of symptoms in the initial stages.

Radiotherapy and surgery can be considered in early stage or locally advanced disease [3, 4], while chemotherapy is the current standard of care in metastatic setting $[5,6]$.

FOLFIRINOX or gemcitabine plus nab-paclitaxel are used in first-line for metastatic PDAC (mPDAC) [5]. In clinical practice there are not clear predictive and prognostic factors that aid in choosing the best regimen for every patient balancing wisely between the benefit and the drug related toxicities. Generally, fit patients are treated with FOLFIRINOX, whereas older and unfit patients receive gemcitabine plus nab-paclitaxel or monochemotherapy.

In this review, we provide an overview of available evidences on prognostic and predictive clinical and biological markers in mPDAC that could help clinicians in treatment decision.

Over the last decades, a number of prognostic and predictive factors has been evaluated in mPDAC.

Among these, we will analyze the evidences on histopathological characteristics, clinical and biohumoral markers (see Tables 1 and 2), with a particular focus on CA19-9, markers of systemic inflammation and immunemodulation, and novel molecular surrogates of survival (Figure 1).

\section{HISTOPATHOLOGICAL CHARACTERISTICS}

Histological analysis of primary tumor or metastatic sites is the only approved diagnostic tool for pancreatic 
Table 1: Promising prognostic and predictive biomarkers

\begin{tabular}{|c|c|c|c|}
\hline Authors & Markers investigated & Role & Prognostic role \\
\hline Lu et al. [40] & $\begin{array}{l}\text { Glypican-1 (GPC1)- } \\
\text { expressing circulating } \\
\text { exosomes }\end{array}$ & $\begin{array}{l}\text { Involvement in angiogenesis and } \\
\text { tumor growth }\end{array}$ & $\begin{array}{l}\text { GPC1 overexpression } \\
\text { associated with poorer OS }\end{array}$ \\
\hline Giovannetti et al. [46] & Circulating miRNA 21 & $\begin{array}{l}\text { Modulation of apoptosis, Akt } \\
\text { phosphorylation, and expression of } \\
\text { genes involved in invasive behavior }\end{array}$ & $\begin{array}{l}\text { High miR- } 21 \text { expression } \\
\text { predicted shorter OS both } \\
\text { in the metastatic and in the } \\
\text { adjuvant setting }\end{array}$ \\
\hline Korpal et al. [50] & miRNA 200 family & $\begin{array}{l}\text { Loss of expression of miRNA- } 200 \\
\text { family members may play a critical } \\
\text { role in enhancing migration and } \\
\text { invasion during cancer progression }\end{array}$ & $\begin{array}{l}\text { Not investigated in clinical } \\
\text { studies }\end{array}$ \\
\hline Liu et al. [56] & lncRNA MALAT1 & $\begin{array}{l}\text { Identified in multiple types of } \\
\text { physiological and pathological } \\
\text { processes, i. e. organizing } \\
\text { nuclearconstruction and modulating } \\
\text { gene expression }\end{array}$ & $\begin{array}{l}\text { Higher expression of } \\
\text { lncRNA MALAT1 was } \\
\text { associated with poorer OS in } \\
\text { patients affected by PDAC }\end{array}$ \\
\hline Ye et al. [57] & lncRNA AFAP1-AS1 & $\begin{array}{l}\text { Knockdown of AFAP1-AS1 could } \\
\text { inhibit cell proliferation, migration, } \\
\text { and invasion of PDAC cells }\end{array}$ & $\begin{array}{l}\text { LncRNA AFAP1-AS1 } \\
\text { overexpression was } \\
\text { associated with lymph } \\
\text { node metastasis, perineural } \\
\text { invasion, and poor survival }\end{array}$ \\
\hline Creemers et al. [70] & CtDNA & N/A & $\begin{array}{l}\text { ctDNA is associated with } \\
\text { poor prognosis in patients } \\
\text { with pancreatic cancer }\end{array}$ \\
\hline
\end{tabular}

The table summarizes the most relevant studies that investigated the prognostic or predictive significance of novel biomarkers.

Table 2: Correlation between inflammatory markers and prognosis

\begin{tabular}{|c|c|c|c|}
\hline Authors & Markers investigated & Study design and setting & Results \\
\hline Martin et al. [90] & NLR; PLR; mGPS & $\begin{array}{l}\text { Retrospective analysis of } 124 \text { patients } \\
\text { with PDAC ( } 84 \text { mPDAC) }\end{array}$ & $\begin{array}{l}\text { NLR; PLR and mGPS resulted } \\
\text { independent prognostic } \\
\text { markers }\end{array}$ \\
\hline Stotz et al. [96] & NLR; mGPS, PLR & $\begin{array}{l}\text { Retrospective evaluation of } 271 \\
\text { inoperable patients with PDAC }\end{array}$ & $\begin{array}{l}\text { NLR }>5 \text { and } m \text { GPS of } 1-2 \\
\text { predicted poorer OS }\end{array}$ \\
\hline Liu et al. [97] & $\mathrm{CRP} /$ Albumin ratio & $\begin{array}{l}\text { Retrospective analysis of } 386 \text { patients } \\
\text { with PDAC ( } 174 \text { mPDAC) }\end{array}$ & $\begin{array}{l}\mathrm{CRP} / \mathrm{Alb} \text { lbmin ratio }>0.180 \\
\text { predicted poorer OS }\end{array}$ \\
\hline Yamada et al. [98] & Neutropenia & $\begin{array}{l}\text { Retrospective analysis of patients } \\
\text { treated with mFOLFIRINOX for } \\
\text { mPDAC }\end{array}$ & $\begin{array}{l}\text { Patients with neutropenia after } \\
\text { chemotherapy experienced } \\
\text { better survival }\end{array}$ \\
\hline Yu et al. [100] & $\begin{array}{l}\text { LDH; LMR; NLR; } \\
\text { PLR; Ca 19-9 }\end{array}$ & $\begin{array}{l}\text { Patients with inoperable PDAC treated } \\
\text { with Gemcitabine based chemotherapy }\end{array}$ & $\begin{array}{l}\text { Ca } 19-9 \geq 1000 \mathrm{IU} / \mathrm{mL} ; \mathrm{LDH} \\
\geq 185 ; \mathrm{NLR} \geq 3.42 ; \mathrm{LMR} \geq 3.19 \\
\text { predicted poorer } \mathrm{OS}\end{array}$ \\
\hline Hwang et al. [103] & mGPS; NLR; PLR & $\begin{array}{l}\text { Patients treated with Gemcitabine and } \\
\text { Nab-Paclitaxel for mPDAC }\end{array}$ & $\begin{array}{l}\text { mGPS } \geq 1 \text { predicted poorer OS; } \\
\text { NLR and PLR did not predict } \\
\text { poorer OS }\end{array}$ \\
\hline
\end{tabular}

NLR: neutrophil to lymphocyte ratio; mGPS: modified Glasgow Prognostic Score; PLR: Platelet to lymphocyte ratio; LMR: lymphocyte to monocyte ratio. 
cancer. Aside from histological diagnosis, tissue analysis has been largely used to identify prognostic features that could influence treatment decision.

In patients undergoing surgery, the histological analysis defines the pathological stage according to the $8^{\text {th }}$ edition of the TNM system [7]. The TNM staging system relies on its reproducibility using anatomic parameters to stratify patients with different survival outcomes [8]. Differently from the 7th edition, the current TNM system does not consider the extension outside the pancreas as $\mathrm{T} 3$, because staging in the $\mathrm{T}$ stage has been replaced by a size-based system [8]. The $\mathrm{N}$ (nodes) parameter has been divided in N1 and N2 depending on the number of positive regional lymph nodes. The number of lymph nodes involved remains the strongest predictor of survival in operable patients [9].

Based on morphological features, different PDAC subtypes have been identified.

Variants with a similar molecular pathogenesis include, among others, adenosquamous carcinoma, anaplastic (undifferentiated) carcinoma and undifferentiated carcinoma with osteoclastic giant cells. Adenosquamous and anaplastic carcinomas carry worse prognosis than classical PDAC [10]. On the other hand, colloid, medullary carcinoma and hepatoid adenocarcinoma are variants with a distinct molecular pathogenesis. Considering their low incidence, the prognostic significance of these pathological characteristic is yet to be defined.

Other prognostic factors identified through pathological analysis of surgical samples are vascular and perineural invasion [11], presence of desmoplastic reaction [12], tumor budding and epithelial to mesenchymal transition (EMT) $[13,14]$.

PDAC produces a strong fibrotic reaction around the primary tumor [12], known as desmoplasia, typical of many malignancies. The fibrotic tissue plays an important role in tumorigenesis, angiogenesis, and resistance to therapy [12]. Cancer-associated fibroblasts (CAFs) are the main effector cells in the desmoplastic reaction, and pancreatic stellate cells (PSCs) are the most important source of CAFs [15]. CAFs have been reported to promote PDAC cell growth, to stimulate stroma production by PSCs and their presence in peritumoral stroma has been associated with worse prognosis [16]. Furthermore, activated CAFs have been implicated in chemo-radiation resistance, for those reasons, therapeutic strategies to target stromal cells are under investigation [15]. CAFs can determine chemotherapy resistance through several molecular mechanisms including

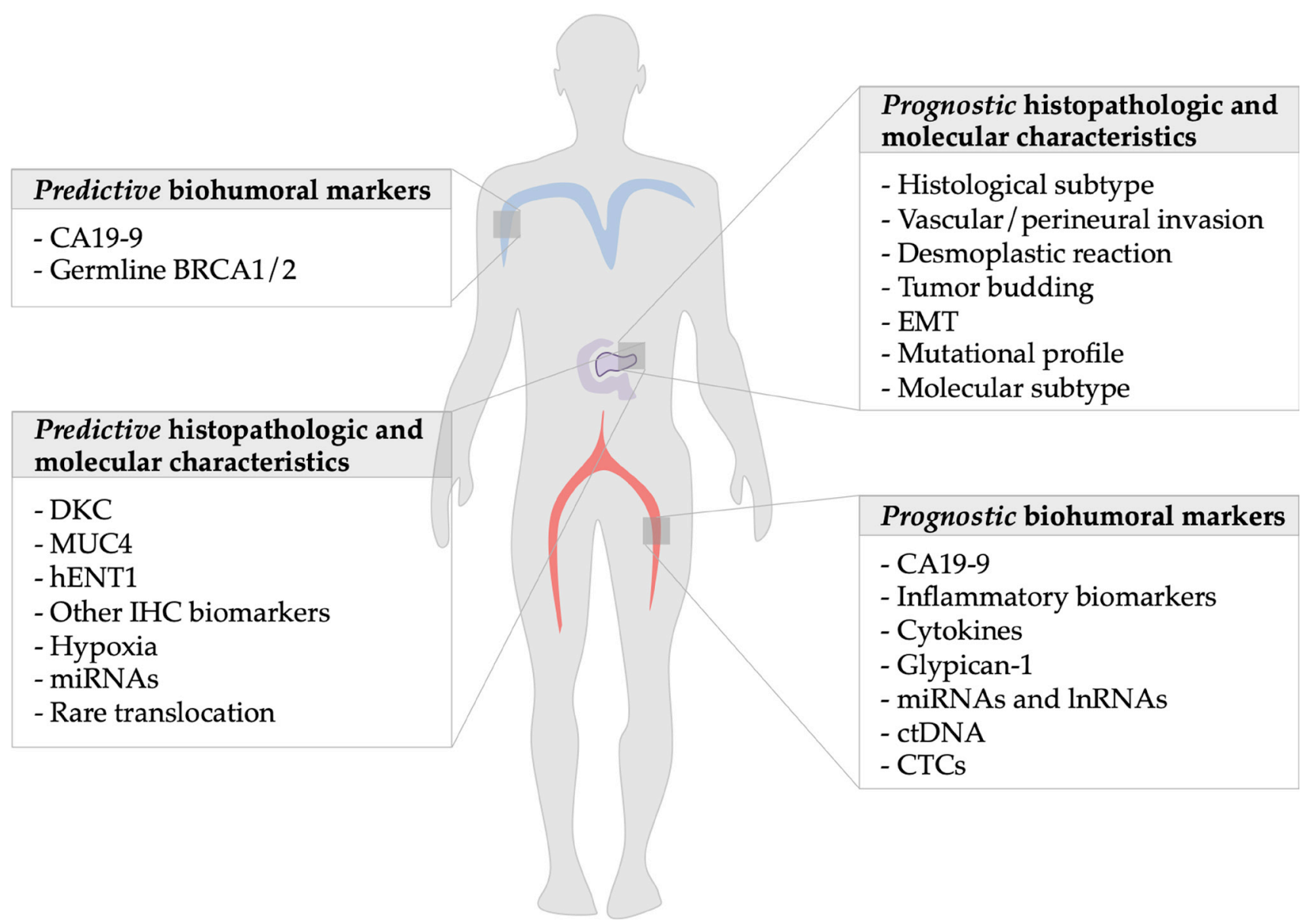

Figure 1: Summary of prognostic factors of metastatic pancreatic ductal adenocarcinoma: The figure shows on the left side the predictive markers discussed in the article and on the right the prognostic ones. 
upregulation of genes involved in extracellular matrix synthesis (SPARC) and in the transduction of chemokines signal (CXCL12/CXCR4), resulting in the induction of epithelial-mesenchymal transition (EMT) [17].

Tumor budding is defined as the presence of detached isolated single cells or small cell clusters (up to five cells) scattered in the stroma at the invasive tumor margin [18]. The presence of tumor budding in surgical samples has been clearly described to be related to advanced pT classification, lymphatic invasion, decreased disease-free and overall survival (DFS; OS) [13]. A correlation between the grade of tumor budding and the immune system invasion has been reported, with high grade of tumor budding being associated with FOXP3+ regulatory $\mathrm{T}$ cells invasion and worse prognosis [19].

Interestingly, an interplay between the presence of tumor budding and the development of EMT is emerging. Experimental data suggest an important role of EMT in invasion and metastasis of PDAC and in the development of resistance to standard treatment [14]. Recent evidences suggest that tumor budding could represent one of the morphological hallmarks of EMT [20, 21]. This hypothesis has been recently confirmed by a meta-analysis [22] that investigated the prognostic role of tumor budding and its relationship with the presence of EMT. Authors concluded that high tumor budding is a risk factor for all-cause mortality and they also confirmed that tumor budding is a morphological aspect intimately associated with EMT [22].

Based on transcriptional profile, Collisson et al. [23] identified 3 subtypes of PDAC: classical, quasimesenchymal and exocrine like. The classical subtype had high expression of adhesion-associated and epithelial genes, the quasi-mesenchymal subtype showed high expression of mesenchyme associated genes and the exocrine-like subtype showed high expression of digestive enzyme genes. Patients with classical subtype showed a better prognosis; each subtype was demonstrated to be an independent prognostic factor for OS. In the pre-clinical setting the quasi-mesenchymal subtype showed better response to gemcitabine [23], however the predictive and prognostic role of this classification has not been tested adequately in the clinical setting and, thus, its application in daily practice is not widely spread.

Waddel et al. [24] in 2015 identified 4 subtypes of PDAC depending on chromosomal structural variations: stable, locally rearranged, scattered and unstable, with potential clinical implications. Genomic instability cosegregated with inactivation of DNA maintenance genes (BRCA1; 2) and has possible clinical implications, especially in predicting response to platinum based therapy. Moffitt et al. [25] identified two types of PDAC, named "basal-like", with the worst prognosis, and "classical" one; interestingly they studied also the stroma, defining 2 types of peri-tumoral stroma: "activated", which had a poor prognosis, and "normal". Stromal subtypes were not correlated with tumor subtypes.

\section{MOLECULAR FACTORS}

On the biological side, many efforts were put to identify protein and their level of expression to correlate to OS, PFS and other parameters in order to understand prognostic and predictive factors of this disease.

Besides classical histopathological characteristics, next generation sequencing (NGS) is allowing us to better recognize mPDAC complex mutational landscape [26] and its association to prognosis. KRAS activation occurs in $92 \%$ of PDAC; whereas TP53, SMAD4 and CDKN2A inactivation is reported in more than $50 \%$ of cases; almost $10 \%$ of PDAC harbors mutations in other genes involved in chromatin remodeling and DNA damage repair, like BRCA1 and 2; PALB2 and ATM [27].

The COMPASS trial was proposed in 2015 to identify predictive mutational features in PDAC trough real-time whole genome sequencing (WGS) and RNA sequencing (RNASeq). It is the first translational study to demonstrate that pancreatic cancer has different molecular and genomic subtypes with different response to chemotherapy. The study demonstrated that Moffitt "classical" tumors respond better to first-line chemotherapy compared to those with "basal-like" tumors. GATA6 expression clearly separated "classical" and "basal-like" PDAC subtypes. EGFR overexpression was associated with the basal subtype. The results from COMPASS trial are encouraging, however they should be interpreted with caution: the primary end-point of the study was the feasibility of the genome sequencing in patients with PDAC and not the definition of genomic subtypes; furthermore the sample was small and there were few patients for each molecular subtypes, weakening, thus, the power of the results [28].

In 2017 Connor et al. [29] proposed a classification based on genomic instability; they identified 4 groups of patients. The first one displayed deficiencies in the mismatch repair (MMR) system; another group of patients had deficiencies in homologous recombination to repair double strand-breaks. The last two were the "agerelated" groups, in which signatures were attributed to mutational processes accumulated over cell divisions. This classification does not carry prognostic value.

The predictive value of these classifications has not been investigated in adequately powered studies.

Several limits apply that hamper the introduction of these analyses in the daily practice: they are costly, they require technological platforms which might not be available, and there is often paucity of available tissue. Furthermore, the molecular subtypes do not correlate with histological variants, contributing to make these classifications difficult to apply on a broad scale.

\section{MICROSATELLITE INSTABILITY}

Microsatellite Instability (MSI) is another molecular feature that can be found in PDAC with an incidence 
between 1 and $2 \%[30,31]$ and it is typically associated with a germline mutation in MMR (mismatch repair) genes and IHC (immunohistochemistry) loss of MMR expression [32]. The prevalence of dMMR/MSI in PDAC is likely very low, but data in this regard are inconsistent. Hu et al. found dMMR in PDAC is a rare event occurring at a frequency of $0.8 \%(7 / 833)$ and all 7 patients with dMMR PDAC were found to have Lynch syndrome [32].

Kim and colleagues conducted a prospective analysis of PD-L1 and MMR IHC on 430 patients (6/430 with PDAC) with advanced gastrointestinal and genitourinary cancers. The dMMR was most common in gastric and colorectal cancer (11.1\%), and nearly $0 \%$ in PDAC [33]. However, some others have reported MSI/ $\mathrm{dMMR}$ in PDAC to be as high as $22 \%$ [34]. Variabilities in histology, sample sizes, and more so due to nonstandardized testing and evolving detection methods could explain this discordance.

The prognostic significance of MSI-H in PDAC is controversial. Some authors did not find prognostic differences between MSI-H and MSS patients [35], while others reported a prolonged survival in MSI-H patients [36]. These contrasting data might be due to the small number of MSI patients. Data about MSI as a predictive factor of response to chemotherapy are based only on a few retrospective studies with a small sample size [37]. Recently, FDA granted the approval of immune checkpoint inhibitors (ICHs) in patients with solid tumors with MSI who failed to respond to first line treatments, including patients with PDAC $[38,39]$. This decision was supported by the data of a phase II clinical trial that demonstrated the efficacy of PD-1 blockade in 12 different types of cancer with MSI-H [39].

The widespread use of ICHs in PDAC has met several limitations: MSI-H that is the only approved predictive biomarker in this setting, is rare and it is not routinely tasted; the availability of pathological tissue is often an issue; which form of testing (IHC vs MSI-PCR vs NGS) and measure (MMR-D vs MSI-H vs mutational load) is used to determine the MSI is controversial; many patients with mPDAC are not fit to receive a second line treatment and ICHs use is not refunded in all countries by national regulatory agencies. Further studies are required to find new predictive biomarkers that define better which patients would benefit most from ICHs therapy; to reach this goal adequately powered clinical trial are highly needed. The increasing availability of NGS will help overcoming some of this limitation, giving simultaneously precious prognostic and predictive information.

\section{GLYPICAN-1 (GPC1)-EXPRESSING CIRCULATING EXOSOMES}

Recently, glypican-1 (GPC1)-expressing circulating exosomes were found to be a potential diagnostic tool for PDAC, however their reliability is not well established and their clinical utility is not defined [40]. GPC-1 is a member of heparin sulfate proteoglycans family, its overexpression has been reported to be involved in angiogenesis and tumor growth in pancreatic, cancer, glioma and breast cancer [41]; its prognostic role has been investigated in a study including 178 PDAC patients from the Cancer Genome Atlas (TCGA) and samples from 186 pancreatic cancer patients. Normal pancreatic tissue did not express GPC-1, whereas it was expressed in PDAC, mainly to promote hypomethylation. GPC-1 expression was significantly related with tumor dedifferentiation and diameter. Multivariate analyses indicated that GPC1 was a significant risk factor for poor OS with a 1.82fold increase in the hazard ratio. Similarly, other authors [41] reported a prognostic role of GPC1 exosomes in 128 PDAC patients at different stages, but they did not describe any diagnostic role of this marker. In conclusion, there are some evidences that GPC-1 exosomes are useful as diagnostic and predictive markers, however their clinical availability is influenced by several limitations: small and non-homogeneous samples, highly specific antiGPC1 antibodies are not readily available [42].

Circulating ribonucleic acids (RNAs), circulating tumor cell DNA (ctDNA) and circulating tumor cells (CTCs) have been extensively investigate.

\section{MICRORNA AND LONG NON-CODING RNA}

MicroRNAs (miRNAs) and long non-coding RNAs (lncRNAs) represent the two major categories of circulating RNAs with prognostic role in PDAC. MiRNAs are very short chains containing about 22 nucleotides normally involved in the transcriptional and translational machinery [43]. LncRNAs are nucleotidic chains exceeding 200 bases that are not translated into proteins. Besides regulating gene transcription at many levels, they are also specifically involved in the epigenetic regulation of DNA [44].

Evaluation of circulating miRNAs and lncRNAs trough liquid biopsies is appealing and has been extensively performed in a variety of cancers, where these molecules have often shown prognostic and predictive roles [45]. In PDAC, both overexpression and downregulation of specific miRNAs have been associated with poor prognosis. Among others, higher levels of circulating miR-21, miR-155 and miR-221 correlated with outcomes [46-49]. Interestingly, the miRNA 200s family has been shown to suppressor tumor progression via EMT inhibition [50]. More recently, a number of multigene prognostic signatures have been proposed, of 2 [51], 5 [52] or 11 microRNAs [53].

In PDAC, also different types of IncRNAs have been investigated, in both clinical and pre-clinical setting.

Many lncRNAs showed prognostic value, although the reproducibility of the results is controversial. The lncRNAs most consistently associated to shorter OS in 
PDAC patients are MALAT1 [54-56], AFAP-AS1 [57, $58,44]$ and UCA1 [44]. Overall, the individual prognostic value of each IncRNAs is too weak for direct clinical development, therefore more recently panels including analysis of the expression levels of up to 12 lncRNAs are being investigated for their prognostic value $[59,60]$.

Importantly, reciprocal regulation mechanisms exist between mRNAs, miRNAs and lncRNAs [61]. A bioinformatics approach identified SCAMP1, HCP5, MAL2 and LINC00511 as key lncRNAs regulating competing endogenous RNA sub-network linked to prognosis in PDAC [61]. In a separate study, miR-200c$3 p$ was predicted to be a direct target of MALAT1, and high expression of MALAT1 combined to low expression of miR-200c-3p correlated with shorter OS [62].

Finally, one of the major limitation of most of these studies is that discerning the prognostic from the predictive value has been hampered by the rather homogenous treatment strategies, often involving gemcitabine-based treatments. Among the few circulating RNAs specifically analyzed in patients undergoing FOLFIRINOX treatment, miR-181a-5p has been proposed as a specific prognostic biomarker [63].

\section{CIRCURLATING TUMOR DNA AND CIRCULATING TUMOR CELLS}

Circurlating Tumor DNA (ctDNA) is a subset of circulating extracellular DNA in plasma (also called cellfree DNA, cfDNA), specifically released from cancer cells.

ctDNA may originate from apoptotic and necrotic tumor cells, from living tumor cells, or even from CTCs; thus, it has a variable half-life from 15 minutes up to $2 \mathrm{~h}$ [64].

ctDNA, being non-invasively detectable in peripheral blood, has been proposed as potential tumor marker and prognostic factor in many types of cancer. Its clinical applications in PDAC are currently under investigation [65]; these include a role in screening, prognostication via the detection of minimal residual disease, early detection of recurrence, and for patients with advanced disease, tumour genotyping and monitoring treatment response [66].

The prognostic role of ctDNA has been mostly investigated in retrospective studies of patients undergoing surgery; in this subset of subjects, the presence of ctDNA, in particular KRAS mutant ctDNA, in plasma has been associated with worse OS and disease free survival (DFS) $[67,68]$. Similarly the detection of ctDNA and the ctDNA variant allelic fraction in patients affected by mPDAC have been reported to be a prognostic factor [69], these findings have, recently, be confirmed by a meta-analysis [70].

The use of ctDNA in clinical practice is promising, but nowadays it cannot be routinely recommended, lacking prospective clinical trials that clearly established the prognostic and predictive value of liquid biopsy in PDAC. Furthermore standardization of sequencing techniques and further development of high-sensitive detection methods are needed [70].

Circulating Tumor Cells (CTCs) are released from primary tumor and/or metastatic sites into the bloodstream, are rare in the circulation and difficult to capture [71], furthermore, the rate of detection varies depending on the sampling site [72]. Studies on the prognostic role of CTCs yielded controversial results [73]; they have been more extensively studied for early detection of PDAC in asymptomatic subjects [74] or as a precocious marker of metastatic disease with different findings [75]. Most of the studies adopted different detection strategies, investigated small and non-homogeneous samples and used different end-points. Given the above issues, our feeling is that the future utility of CTCs is not as promising as that of ctDNA and miRNA.

\section{CA19-9}

The serum carbohydrate antigen CA19-9, a sialylated Lewis blood group antigen, is a tumorassociated antigen that has been shown to be a serum marker for pancreatic cancer [76]. It is the only FDA approved prognostic marker for PDAC [77].

Most of the studies investigating the prognostic role of CA19-9 are retrospective and focus on heterogeneous populations that received preeminently gemcitabine monochemotherapy [78-80]. However, up to date, the standard of care for PDAC is a combined regimen with gemcitabine and nab-paclitaxel or FOLFIRINOX. In the ANICE Pac study, the authors retrospectively investigated prognostic factors in patients treated with gemcitabine plus nab-paclitaxel in real life and found normal baseline level of CA19-9 to be an independent prognostic marker for better survival [81].

CA19-9 remains the only biomarker recommended for clinical use by the National Comprehensive Cancer Network (NCCN) guidelines for pancreatic cancer and it is recognized as the most clinically useful biomarker [58]; its sensitivity and specificity are $80 \%$ and $80-90 \%$ respectively [82], its level is strongly correlated with the tumor burden [83].

Despite its approval, it is far to be an ideal prognostic biomarker: it can yield false negative results in patients who do not express the Lewis blood antigen, accounting from $5 \%$ to $10 \%$ of general population [82], as it can give false positive results in case of pancreatitis, cholestasis, diabetes, cirrhosis or other cancers [82]. Many studies described the prognostic role of CA19-9 decline after curative surgery [84] and during chemotherapy [85, 86], especially an early decrease during treatment has been supposed to foresee a longer PFS [87] in patients receiving gemcitabine-nabpaclitaxel and FOLFIRINOX. Conversely there are also data that do not support these findings [88].

In patients treated in ACCORD11/PRODIGE4 trial, an early (8 weeks) CA19-9 decrease with respect to $20 \%$ was predictive of better PFS and could help to evaluate the 
efficacy of chemotherapy regimen such as FOLFIRINOX or gemcitabine [87].

Regard OS, a decrease $>20 \%$ in CA19-9 level during chemotherapy was associated with a longer survival when compared to those with a CA19-9 decrease $<20 \%$ [86].

It should be underlined that some authors investigated the nadir of CA19-9 response during chemotherapy as a surrogate marker for survival and not as a predictive or prognostic factor [89].

\section{INFLAMMATORY MARKERS}

Chronic inflammation represents both an important etiologic factor in the development of pancreatic cancer as well as a reactive process to pancreatic cancer [90].

The role of systemic inflammation has been studied in several cancers; the most investigated inflammation markers are: C-reactive protein (CRP) and albumin combined as the modified Glasgow Prognostic Score (mGPS), neutrophil- lymphocyte ratio (NLR), plateletlymphocyte ratio (PLR), white cell count and CRP as the prognostic index (PI) and the combination of albumin and lymphocyte count in prognostic nutritional index (PNI). Those markers have been studied in several solid tumors [91], such as breast cancer [92], hepatocellular carcinoma [93], and colorectal cancer, in both resected [91] and metastatic patients [94].

An increase in inflammatory markers is associated with decreased survival in metastatic pancreatic cancers patients.

The first data about inflammation markers in mPDAC have been reported by Wang et al. in 2012 [95]: in 177 patients NLR $>5$ was associated with worse survival, PLR, mGPS, PI and PNI were not.

Similar results were published by Stotz et al. [96] in a cohort of 371 patients: in the unresectable group, the mGPS was associated with poor cancer specific survival only in univariate analysis.

Martin et al. [90] retrospectively analyzed the prognostic role of NLR, PLR and mGPS, in 124 PDAC patients ( 84 with mPDAC and 40 with locally advanced disease) showing that these markers were independent prognostic factors both on univariate as well as multivariate analysis. Liu et al. [97] prospectively studied the prognostic role of C-reactive protein (CRP)/albumin (Alb) ratio in $386 \mathrm{PDAC}$ patientsCRP/Alb ratio, diameter of the primary tumor, CA19-9, and TNM stage were incorporated in the multivariate analysis, showing that $\mathrm{CRP} / \mathrm{Alb}$ ratio, diameter and TNM stage were independent factors for prognosis. When stratified by TNM stage, patients in stages III and IV whose CRP/Alb ratio $>0.180$ had remarkably poorer OS compared with patients with $\mathrm{CRP} / \mathrm{Alb}$ ratio $<0.180$.

Considering patients that received modified FOLFIRINOX, Yamada et al. [98], found that the development of neutropenia after chemotherapy correlates with better OS. Moreover, there was a significant correlation between OS and the grade of neutropenia. Similar results have been published for patients receiving gemcitabine monotherapy [99].

There are many reasons that can explain the prognostic role of neutropenia: first of all, as explained above, systemic inflammation plays a tumor promoting role. Furthermore, it has been supposed that myelosuppression occurring in severe neutropenic patients contributes to improve the prognosis of the patients by reducing the level of myeloid-derived suppressing cells, which in advanced stage of cancer, inhibit the anti-tumoral activity of CD4+ T cells.

Yu et al. [100] in a cohort of 364 patients affected by advanced or metastatic PDAC receiving gemcitabinebased chemotherapy described an association between high LDH (>185 Iu/mL) and inflammation markers (NLR/LMR/PLR). Poor OS was predicted by tumor stage, CA19-9 levels, serum LDH levels, NLR and lymphocyte/ monocyte ratio. Serum LDH levels positively correlated with NLR and PLR, but negatively correlated with LMR.

LDH is a key enzyme in glycolysis, required for the anaerobic conversion of pyruvate to lactate [101]; under physiological conditions, serum LDH concentrations range from $120-250 \mathrm{IU} / \mathrm{mL}$ and increase in patients with tumors, liver disease or cardiopathy. LDH levels correlate with tumor burden and may reflect tumor growth and invasive potential [102]. Hypoxia and systemic inflammation are associated with the advanced stages of pancreatic cancer, and serum LDH levels serve as an indirect marker of tumor hypoxia [100]. In a group of patients receiving gemcitabine plus nab-paclitaxel, Hwang et al. [103], reported that high mGPS was an independent prognostic factor, whereas, NLR and PLR did not predict OS.

We know that inflammation is pivotal in pancreatic cancer prognosis in many different ways. Common mediators have been shown to regulate both inflammatory and oncogenic pathways involved in the development and disease progression [104]. Both inflammatory and antiinflammatory cytokines have been studied in pancreatic cancer [104]; cytokines expression correlates negatively with cachessia, sarcopenia and performance status (PS) [105]. Pro-inflammatory cytokines IL-6 and IL-8, as well as anti-inflammatory cytokines IL-10 and tumor growth factor-beta (TGF- $\beta$ ), have been commonly shown to be elevated in pancreatic patients [105]. Mitsunga et al. [106] evaluated the prognostic role of Il-6 and IL-1 $\beta$ in 60 patients receiving gemcitabine based chemotherapy for PDAC; they found that high IL-6 and IL1beta before the start of systemic treatment were associated with poorer OS. Similar results have been published by Farren et al. [107] on 73 patients with metastatic/inoperable PDAC: they collected serum before the start of chemotherapy and analyzed a panel of 32 cytokines/chemokines. IL-6 and IL-10, were significantly associated with OS. Of the two cytokines, the effect of IL-6 appeared to be 
dominant. Namely, patients with higher IL-6 levels had worse survival than those with low IL-6, regardless of their IL-10 status. The authors also evaluated the phenotype of circulating immune cells: the expression of CD45RO, a marker of not-naïve T-cells, on CD4+ T cells was significantly associated with OS, though CD45RO expression on CD8+ T cells was not. The frequency of CD8+ T cells expressing the T cell checkpoint molecule CTLA-4 was negatively associated with survival. Paradoxically, CD4+ T cell expression of TIM3, another immunosuppressive molecule, was positively associated with PDAC survival.

Furthermore, systemic inflammation causes metabolic alterations that influence body composition leading to sarcopenia and cachexia, which are recognized to be negative prognostic factors and are known to modify drugs metabolism, increasing the risk of adverse events that require chemotherapy suspension [108]. In clinical practice the most common index used to estimate body composition are BMI and body surface area; other index, as skeletal muscle index (SMI) and skeletal muscle area (SMA) have been demonstrated to provide a better description of body tissues, however they are not widely available, being expensive and time consuming [109]. Furthermore, adjusting chemotherapy dose depending on skeletal muscle did not reduce chemotherapy toxicity in patients treated with gemcitabine plus nab-paclitaxel [110]; nowadays, based on available data, the precise evaluation of body composition is not required to decide the treatment. The prognostic role of body composition has been largely studied in other gastro-intestinal cancers [111]. Some authors have investigated the role of sarcopenia in PDAC prognosis [112], however, due to the limited number of studies available for inclusion, the authors could only conclude that weight loss and sarcopenic obesity might be considered as poor prognostic factors in this disease. A meta-analysis of 11 studies, comprising 2297 PDAC patients in different stages demonstrated that sarcopenia was significantly associated with poorer OS. Sarcopenic obesity was reported in $0.6 \%$ to $25.0 \%$ of patients and was also significantly associated with poorer OS.

In general, PDAC is an immunologically 'cold' tumor due to its low mutational load, dense desmoplasia and rigid extracellular matrix architecture, which restricts the access of effector immune cells to tumor islands; consequently, metastatic pancreatic cancer has shown poor response to immune checkpoint inhibitors [113], since the immune-modulating effect of immune checkpoint inhibitors does not reverse the immunequiescent environment of pancreatic cancer. Combinations strategies with immune checkpoint inhibitors and other drugs that could alter the immunosuppressive feature of PDAC, like cancer specific vaccines are currently under investigation, but they are far to be available in clinical practice [114].

\section{NOMOGRAMS AND PROGNOSTIC SCORES}

Many nomograms have been validated to predict prognosis in PDAC. One of the strengths of a nomogram is the ability to integrate multiple prognostic factors into a single numerical estimate of survival in an individual patient and thus provides an individualized prediction of survival [115].

Up to date several prognostic models have been proposed in pancreatic cancer, even if in different stages [116-118]. The most widely used prognostic factors included age, sex, tumor size, PS, regional lymph node and distant metastasis, CA19-9 and back pain.

The first nomograms were validated for resected PDAC patients [117] in 2014. Authors prospectively considered a cohort of 531 patients with stage IIIIV pancreatic cancer treated with gemcitabine based chemotherapy including six variables: age; sex; PS; tumor size; distant metastasis and regional lymph node.

The nomogram was validated to predict survival probability at 6 - 12- and 18 months, they demonstrated its superiority compared to AJCC TNM staging system in predicting survival.

On the basis of nomogram-predicted survival probabilities, the patients were categorized into the following quartiles of risk: very low ('Total Points': 954); low (55-81); high (82-105); and very high (:106). The survival times were significantly differentiated between the groups and the median survival time in the very low-, low-, high-, and very high-risk groups were 17.5 (95\% CI: 15.4-22.9), 13.7 (95\% CI: 11.6-16.0), 8.9 (95\% CI: 7.9-10.4), and 5.5 (95\% CI: 4.7-7.5) months, respectively.

In 2016, Vernerey et al. [118] proposed a prognostic nomogram for locally PDAC patients, including as parameters: age, pain, tumor size, albumin and CA19-9, which were all independent prognostic factors. Kou et al. [119] validated a prognostic model on 306 patients receiving gemcitabine chemotherapy, based on the regression coefficients of the six significant independent negative prognostic factors (PS, distant metastatic disease, the status of recurrent or initially unresectable disease, CEA ( $\geq 5.0 \mathrm{ng} / \mathrm{ml})$ and CA19-9 level $(\geq 1,000 \mathrm{U} / \mathrm{ml})$, and neutrophil/lymphocyte ratio (NLR) ( $\geq 5)$.

Recently Hang et al. [120] developed and validated a prognostic nomogram considering data from the comparative arm of three trials where metastatic pancreatic patients received gemcitabine monotherapy. They inserted five independent prognostic elements: CA19-9; albumin; absolute neutrophil count (ANC), PS and liver metastasis. Nomogram was validated on an extern cohort to predict survival at 3, 6, 9 and 12 months and patients were divided into 2 groups on the basis of an optimal cut-off value of NTP (nomogram total point) identified by ROC curve: a low risk group (NTP $<109, N=100)$ and a high risk group (NTP $\geq 109, N=306$ ). The median OS of the low risk 
group and high risk group was 11.7 (95\% CI: 9.7-13.8) and 5.6 months (95\% CI: 5.0-6.1), respectively. To give a more specific stratification for patients with high risk, the patients were further categorized into the following tertiles of risk: low risk group (NTP $<111, N=110$ ), intermediate risk group $(111 \leq \mathrm{NTP}<144, N=186)$ and high risk group (NTP $\geq 144, N=110$ ). The OS was significantly different among the 3 subgroups $(\mathrm{P}<.001)$. The median OS was 3.7 months (95\% CI: 3.2-4.3) in high risk group, 7.0 (95\% CI: 6.4-7.6) months in intermediate risk group and 11.7 (95\% CI: 10.1-13.3) months in low risk group, respectively.

In conclusion, nomograms have more accuracy than single factors in predicting prognosis. However, considering the heterogeneity of the samples and the different setting investigated, up to day, there are not sufficient data to recommend a nomogram over another. Furthermore, in clinical practice they are not widely used and international guidelines do not recommend the use of nomograms as predictive tools to guide treatment decisions.

\section{MECHANISMS OF DRUG RESISTANCE}

Molecular pathway involved in drugs pharmacokinetic seems to correlate with OS and PFS. Resistant tumors often have an altered metabolism of gemcitabine. Ohmine et al. demonstrated that deoxycytidine kinase (DKC) protein level correlates with PFS in patients treated with gemcitabine. DKC is an enzyme, which converts $\mathrm{dFdC}$ (molecular name of gemcitabine) to $\mathrm{dFdC}$ monophosphate, contributing to the intracellular activation of the drug. It has demonstrated to be determinant for gemcitabine sensitivity both in vitro and in vivo [121].

In pancreatic cancer, MUC4 is involved in the acquisition of an aggressive phenotype in the early steps of carcinogenesis [122].

In the study of Shrypek et al., the expression of MUC4 in pancreatic cancer cells led to a marked decrease in hCNT1 and hCNT3 transporters which lead gemcitabine inside the tumoral cells, so the expression of this protein could be investigated as potential predictive marker of resistance to chemotherapy regimen containing gemcitabine [123].

The loss of MUC4 was also demonstrated to increase sensibility of cell cultures (CAPAN-2 cells) to 5 -fluorouracil. This protein is implicated in the expression level of MRP3 and MRP4, drug-detoxifying channels. While decreased expression of MRP3 did not modify cytotoxicity of gemcitabine, MRP4 repression demonstrated to be linked to a statistically significant increase in survival in pancreatic cancer cell exposed to gemcitabine [122]. Furthermore, MRP expression confers resistance to campotectin, such as irinotecan [124] which is used in the treatment of pancreatic cancer. In PDAC, tumor environment is characterized by hypoxia that contributes to cancer progression and resistance to chemotherapy. Gemcitabine sensitivity in CAPAN-2 (Human Pancreatic Cancer Cell Line) cells was significantly decreased under hypoxia. Overexpression of HIF -1a, a transcription factor expressed to compensate for the hypoxic microenvironment and overexpressed in many tumors, resulted in decreased gemcitabine sensitivity. Chemoresistance induced by hypoxia is due to the regulation of ABCG2 (ATP-binding cassette subfamily G member 2) which is one of the major multidrug-resistance pumps through the activation of ERK1/2/HIF-1a. ABCG2 could serve as a predictor of gemcitabine response and potentially as a target for chemotherapy of pancreatic cancer.

In patients treated with irinotecan, an association between high expression of CES2, an enzyme that produces irinotecan active metabolite $\mathrm{SN}-38$, and longer survival, was described [125]. ERCC1 overexpression showed to be significantly linked to shorter survival and worse disease control rate, even if in a retrospective study with small sample size [126]. A negative predictive role for ERCC1 was suggested by Mancuso et al., who reported that high ERCC1 expression was associated with shorter survival in patients with advanced pancreatic cancer treated with platinum therapy [127].

Data are however not concordant. Tezuka et al., even if in small number of patients (34), did not find statistical association between ERCC1, ERCC2, ERCC4, GSTPi and response to FOLFIRINOX [128]. Otherwise, the proteins KRT81 and HNF1A expression showed to be linked to FOLFIRINOX or gemcitabine sensitivity.

The study of Muckenhuber et al. [129] suggests that KRT81-positive patients might not derive a relevant advantage from both an intensive chemotherapy regimen as FOLFIRINOX and gemcitabine, while HNF1A-positive patients might benefit from FOLFIRINOX based therapy with a better response compared to gemcitabine treated patients.

hENT1 (Human Equilibrative Nucleoside Trasporter 1) is one of the major gemcitabine transporters and was studied as a predictive factor of response to this drug. Its overexpression is associated with a longer OS and PFS in PDAC [130].

Most of the above reported predictive factors are to be searched on histological samples, whereas novel circulating predictive biomarkers are emerging. Among these, circulating miRNAs are gaining relevance. In particular, focusing on gemcitabine resistance, it was showed, that higher serum mi-RNA 21 and mi-RNA 155 levels were observed in patients that did not obtain response to gemcitabine $[131,48]$. However, those data require to be confirmed by broader and adequately powered studies to distinguish better between the prognostic and the predictive role of those markers. In patients receiving FOLFIRINOX for locally advanced or mPDAC, plasma miR-181a-5p was significantly downregulated in nonprogressive patients after FOLFIRINOX; this aspect did not correlate with survival in patients treated with gemcitabine plus nab-paclitaxel, confirming the predictive significance of this marker [63]. 
Table 3: Mechanisms of drug resistance

\begin{tabular}{|c|c|c|c|}
\hline Authors & Study design & Molecules involved & Results \\
\hline $\begin{array}{l}\text { Meijer et al. } \\
{[63]}\end{array}$ & $\begin{array}{l}\text { Microarray-based profiling to discover } \\
\text { deregulated miRNAs in pre- and post- } \\
\text { chemotherapy plasma according to } \\
\text { progression-free survival (PFS) after } \\
\text { FOLFIRINOX }\end{array}$ & & $\begin{array}{l}\text { Plasma miR-181a-5p was } \\
\text { significantly downregulated in } \\
\text { non-progressive patients after } \\
\text { FOLFIRINOX }\end{array}$ \\
\hline $\begin{array}{l}\text { Ohmine et al. } \\
\text { [121] }\end{array}$ & $\begin{array}{l}\text { Analysis of Deoxycytidine kinase } \\
\text { (DKC) expression on surgical samples } \\
\text { of patients treated with gemcitabine }\end{array}$ & $\begin{array}{l}\text { DKC activates Gemcitabine } \\
\text { in PDAC }\end{array}$ & $\begin{array}{l}\text { DKC expression is associated } \\
\text { with increased OS in patients } \\
\text { receiving Gemcitabine }\end{array}$ \\
\hline $\begin{array}{l}\text { Shrypek et al. } \\
{[123]}\end{array}$ & $\begin{array}{l}\text { Study of the expression of MUC } 4 \text { on } \\
\text { PDAC cells }\end{array}$ & $\begin{array}{l}\text { MUC4 downregulates } \\
\text { expression of hCNT1 and } \\
\text { hCNT3 transporters leading } \\
\text { gemcitabine inside tumoral } \\
\text { cells }\end{array}$ & $\begin{array}{l}\text { MUC } 4 \text { expression in PDAC } \\
\text { is associated with gemcitabine } \\
\text { resistance }\end{array}$ \\
\hline $\begin{array}{l}\text { Capello et al. } \\
{[125]}\end{array}$ & $\begin{array}{l}\text { Retrospective analysis of } \\
\text { Carboxylesterase } 2 \text { (CES2) expression } \\
\text { on surgical samples of patients with } \\
\text { PDAC that did and did not receive pre- } \\
\text { operative chemotherapy }\end{array}$ & $\begin{array}{l}\text { CES2, by mediating the } \\
\text { intratumoral activation of } \\
\text { irinotecan, is a contributor } \\
\text { to FOLFIRINOX sensitivity } \\
\text { in pancreatic cancer }\end{array}$ & $\begin{array}{l}\text { Patients treated with } \\
\text { FOLFIRINOX with higher } \\
\text { expression of CES2 on PDAC } \\
\text { samples had better prognosis }\end{array}$ \\
\hline $\begin{array}{l}\text { Mancuso et al. } \\
{[127]}\end{array}$ & $\begin{array}{l}\text { Retrospective analysis of ERCC1 } \\
\text { expression on tissue from } \\
\text { patients treated with platinum or } \\
\text { fluoropyrimidine based therapy }\end{array}$ & $\begin{array}{l}\text { Excision repair cross } \\
\text { complementing } 1 \text { (ERCC1) } \\
\text { participates to repair } \\
\text { mechanism of cisplatin- } \\
\text { induced DNA adducts in } \\
\text { cancer cells }\end{array}$ & $\begin{array}{l}\text { ERCC1 expression was related } \\
\text { to shorter OS in patients } \\
\text { receiving platinum-based } \\
\text { therapy }\end{array}$ \\
\hline $\begin{array}{l}\text { Muckenhuber } \\
\text { et al. [129] }\end{array}$ & $\begin{array}{l}\text { Prospective comparative analysis of } \\
\text { Hepatocyte Nuclear Factor-1A and } \\
\text { Cytokeratin- } 81 \text { (HNF1A/KRT81) } \\
\text { expression on samples from patients } \\
\text { not receiving chemotherapy, receiving } \\
\text { FOLFIRINOX or Gemcitabine }\end{array}$ & & $\begin{array}{l}\text { Patients with a KRT81-positive } \\
\text { subtype did not benefit from } \\
\text { FOLFIRINOX therapy, } \\
\text { whereas those with HNF1A- } \\
\text { positive tumors responded } \\
\text { better compared with } \\
\text { gemcitabine-based treatment }\end{array}$ \\
\hline $\begin{array}{l}\text { Song et al. } \\
\text { [131] }\end{array}$ & $\begin{array}{l}\text { Retrospective analysis of serum } \\
\text { expression of mi-RNA } 21 \text { in patients } \\
\text { affected by PDAC }\end{array}$ & $\begin{array}{l}\text { Histone acetylation levels } \\
\text { at miR- } 21 \text { promoter } \\
\text { were increased in PDAC } \\
\text { cells after treatment with } \\
\text { gemcitabine }\end{array}$ & $\begin{array}{l}\text { Serum miR-21 levels were } \\
\text { increased in gemcitabine- } \\
\text { resistant PDAC patients } \\
\text { compared with gemcitabine- } \\
\text { sensitive subjects }\end{array}$ \\
\hline
\end{tabular}

The table summarizes the most relevant studies that investigated the mechanisms of drug resistance or sensitivity.

Given the crescent use of NGS in clinical practice, many previously unknown gene mutations are emerging as predictive markers, potentially targetable by specific innovative therapies. These alterations include recurrent NRG1 rearrangements that drives PDAC development through aberrant ERBB receptor-mediated signaling [132]; the oncogenic DCTN1-ALK fusion and the RRAS mutation that are associated with the development of PDAC in the absence of the KRAS mutation. Constitutional activation of DCTN1-ALK fusion protein was suppressed by the anaplastic lymphoma kinase (ALK) tyrosine kinase inhibitors crizotinib and alectinib. Thus, a small subset of PDAC patients might benefit from therapy using these inhibitors [133]. NTRK fusion is described to be present in $<1 \%$ of PDAC; this genetic alteration has been specifically targeted by new drugs like entrectinb and larotrectinib that have been tested in basket trials, that select patients independently from the histology, but on the basis of specific molecular alterations. In patients that have received multiple treatments and are fit to be enrolled in clinical trials, it seems reasonable to look for specific, even rare, molecular alterations that make patients eligible to receive targeted therapy. It is worth highlighting, however, that precision medicine is far to be the standard of care for PDAC and nowadays, it is confined to the clinical trial setting.

In Table 3 the main studies which evaluated the molecular pathways involved in drugs resistance or sensibility are summarized. 


\section{BRCA 1 AND 2}

Pancreatic cancer is the third most common cancer associated with mutations in BRCA genes. BRCA2 and BRCA1 mutations cause respectively a 3.5-10 fold and 2.5 fold higher risk of PDAC. Not by chance, BRCA 2 mutations are described to occur frequently in Familiar Pancreatic Cancer (FPC) [134] and are described in almost $4-7 \%$ of patients with PDAC [135].

BRCA genes mutations are associated with defect in homologous recombination repair of DNA doublestrand breaks and confer sensibility to poly (adenosine diphosphate-ribose) polymerase (PARP) inhibition [136]. PARP inhibition leads to accumulation of DNA damage and tumor cell death [137].

There are just few data on the use of PARP inhibitors in this disease and they refer to mixed cohorts in early phase trials which showed prolonged partial response for 1-2 years $[138,139]$. BRCA mutation is responsible of higher sensitivity to platinum-based therapy. In a retrospective evaluation of 43 patients diagnosed with stage III or IV of BRCA mPDAC, patients treated with platinum-based regimens had median OS that was 13 months longer compared with patients not treated with platinum (median 22 vs 9 months) [140].

Recently Golan et al. demonstrated that olaparib maintenance achieved a longer PFS compared to placebo in metastatic pancreatic cancer patients who had a germline BRCA 1 or 2 mutation. Patients eligible for olaparib had received at least 16 weeks of first line platinum-based chemotherapy. mPFS was almost doubled in the experimental group in comparison with placebo group (7.4 months vs 3.8 months) and also difference in median duration of response was significant (24.9 months vs 3.7 months). Even though no benefit in OS was found and the experimental treatment was tested only as maintenance in patients carrying BRCA mutations who had not progressed during first line platinum-based chemotherapy [141]. BRCA germline mutations result a predictive factor of response to PARP inhibitors. Consequently, BRCA testing is likely to spread in everyday clinical practice and represents a potential answer to an unmet clinical need in the field of mPDAC treatment.

\section{CONCLUSIONS}

In a changing landscape consisting in new chemotherapy regimens, immunotherapy and target therapies, the identification of prognostic and predictive factors is needed in view of a personalized medicine which aim to choose the best therapy for the right patient. Further studies are needed to better understand pancreatic cancer biology and to identify prognostic and predictive factors, which could help clinicians to stratify pancreatic cancer patients and improve their prognosis.

\section{Author contributions}

The authors contributed equally to the manuscript.

\section{CONFLICTS OF INTEREST}

The authors declare no conflicts of interest.

\section{FUNDING}

No financial support was received for the present manuscript. This research received no external funding.

\section{REFERENCES}

1. Jemal A, Bray F, Center MM, Ferlay J, Ward E, Forman D. Global cancer statistics. CA Cancer J Clin. 2011; 61:69-90. https://doi.org/10.3322/caac.20107. [PubMed]

2. Siegel R, Naishadham D, Jemal A. Cancer statistics, 2013. CA Cancer J Clin. 2013; 63:11-30. https://doi.org/10.3322/ caac. 21166. [PubMed]

3. Varadhachary GR, Tamm EP, Abbruzzese JL, Xiong HQ, Crane CH, Wang H, Lee JE, Pisters PW, Evans DB, Wolff RA. Borderline resectable pancreatic cancer: definitions, management, and role of preoperative therapy. Ann Surg Oncol. 2006; 13:1035-46. https://doi. org/10.1245/ASO.2006.08.011. [PubMed]

4. Halperin DM, Varadhachary GR. Resectable, borderline resectable, and locally advanced pancreatic cancer: what does it matter? Curr Oncol Rep. 2014; 16:366. https://doi. org/10.1007/s11912-013-0366-9. [PubMed]

5. Conroy T, Desseigne F, Ychou M, Bouché O, Guimbaud R, Bécouarn Y, Adenis A, Raoul JL, Gourgou-Bourgade S, de la Fouchardière C, Bennouna J, Bachet JB, KhemissaAkouz F, et al, and Groupe Tumeurs Digestives of Unicancer, and PRODIGE Intergroup. FOLFIRINOX versus gemcitabine for metastatic pancreatic cancer. $\mathrm{N}$ Engl J Med. 2011; 364:1817-25. https://doi.org/10.1056/ NEJMoa1011923. [PubMed]

6. Von Hoff DD, Ervin T, Arena FP, Chiorean EG, Infante J, Moore M, Seay T, Tjulandin SA, Ma WW, Saleh MN, Harris M, Reni M, Dowden S, et al. Increased survival in pancreatic cancer with nab-paclitaxel plus gemcitabine. N Engl J Med. 2013; 369:1691-703. https://doi.org/10.1056/ NEJMoa1304369. [PubMed]

7. Haeberle L, Esposito I. Pathology of pancreatic cancer. Transl Gastroenterol Hepatol. 2019; 4:50. https://doi. org/10.21037/tgh.2019.06.02. [PubMed]

8. van Roessel S, Kasumova GG, Verheij J, Najarian RM, Maggino L, de Pastena M, Malleo G, Marchegiani G, Salvia R, Ng SC, de Geus SW, Lof S, Giovinazzo F, et al. International Validation of the Eighth Edition of the American Joint Committee on Cancer (AJCC) TNM Staging System in Patients With Resected Pancreatic 
Cancer. JAMA Surg. 2018; 153:e183617. https://doi. org/10.1001/jamasurg.2018.3617. [PubMed]

9. Allen PJ, Kuk D, Castillo CF, Basturk O, Wolfgang CL, Cameron JL, Lillemoe KD, Ferrone CR, MoralesOyarvide V, He J, Weiss MJ, Hruban RH, Gönen M, et al. Multi-institutional Validation Study of the American Joint Commission on Cancer (8th Edition) Changes for $\mathrm{T}$ and N Staging in Patients With Pancreatic Adenocarcinoma. Ann Surg. 2017; 265:185-191. https://doi.org/10.1097/ SLA.0000000000001763. [PubMed]

10. Komatsu H, Egawa S, Motoi F, Morikawa T, Sakata N, Naitoh T, Katayose Y, Ishida K, Unno M. Clinicopathological features and surgical outcomes of adenosquamous carcinoma of the pancreas: a retrospective analysis of patients with resectable stage tumors. Surg Today. 2015; 45:297-304. https://doi.org/10.1007/s00595014-0934-0. [PubMed]

11. Bilici A. Prognostic factors related with survival in patients with pancreatic adenocarcinoma. World J Gastroenterol. 2014; 20:10802-12. https://doi.org/10.3748/wjg.v20. i31.10802. [PubMed]

12. Apte MV, Park S, Phillips PA, Santucci N, Goldstein D, Kumar RK, Ramm GA, Buchler M, Friess H, McCarroll JA, Keogh G, Merrett N, Pirola R, Wilson JS. Desmoplastic reaction in pancreatic cancer: role of pancreatic stellate cells. Pancreas. 2004; 29:179-87. https://doi. org/10.1097/00006676-200410000-00002. [PubMed]

13. Karamitopoulou E, Zlobec I, Born D, Kondi-Pafiti A, Lykoudis P, Mellou A, Gennatas K, Gloor B, Lugli A. Tumour budding is a strong and independent prognostic factor in pancreatic cancer. Eur J Cancer. 2013; 49:1032-39. https://doi.org/10.1016/j.ejca.2012.10.022. [PubMed]

14. Kohler I, Bronsert P, Timme S, Werner M, Brabletz T, Hopt UT, Schilling O, Bausch D, Keck T, Wellner UF. Detailed analysis of epithelial-mesenchymal transition and tumor budding identifies predictors of long-term survival in pancreatic ductal adenocarcinoma. J Gastroenterol Hepatol. 2015 (Suppl 1); 30:78-84. https://doi.org/10.1111/ jgh.12752. [PubMed]

15. Nielsen MF, Mortensen MB, Detlefsen S. Key players in pancreatic cancer-stroma interaction: cancer-associated fibroblasts, endothelial and inflammatory cells. World J Gastroenterol. 2016; 22:2678-700. https://doi.org/10.3748/ wig.v22.19.2678. [PubMed]

16. Erkan M, Michalski CW, Rieder S, Reiser-Erkan C, Abiatari I, Kolb A, Giese NA, Esposito I, Friess H, Kleeff J. The activated stroma index is a novel and independent prognostic marker in pancreatic ductal adenocarcinoma. Clin Gastroenterol Hepatol. 2008; 6:1155-61. https://doi. org/10.1016/j.cgh.2008.05.006. [PubMed]

17. Zhang L, Yao J, Li W, Zhang C. Micro-RNA-21 Regulates Cancer-Associated Fibroblast-Mediated Drug Resistance in Pancreatic Cancer. Oncol Res. 2018; 26:827-35. https://doi. org/10.3727/096504017X14934840662335. [PubMed]
18. Prall F. Tumour budding in colorectal carcinoma. Histopathology. 2007; 50:151-62. https://doi.org/10.1111/ j.1365-2559.2006.02551.x. [PubMed]

19. Wartenberg M, Cibin S, Zlobec I, Vassella E, EppenbergerCastori S, Terracciano L, Eichmann MD, Worni M, Gloor B, Perren A, Karamitopoulou E. Integrated Genomic and Immunophenotypic Classification of Pancreatic Cancer Reveals Three Distinct Subtypes with Prognostic/Predictive Significance. Clin Cancer Res. 2018; 24:4444-54. https:// doi.org/10.1158/1078-0432.CCR-17-3401. [PubMed]

20. Gurzu S, Banias L, Kovacs Z, Jung I. Epithelialmesenchymal transition of tumor budding in colorectal cancer: the mystery of CD44-positive stromal cells. Hum Pathol. 2018; 71:168-69. https://doi.org/10.1016/j. humpath.2017.07.019. [PubMed]

21. Wang C, Huang H, Huang Z, Wang A, Chen X, Huang L, Zhou X, Liu X. Tumor budding correlates with poor prognosis and epithelial-mesenchymal transition in tongue squamous cell carcinoma. J Oral Pathol Med. 2011; 40:545-51. https:// doi.org/10.1111/j.1600-0714.2011.01041.x. [PubMed]

22. Lawlor RT, Veronese N, Nottegar A, Malleo G, Smith L, Demurtas J, Cheng L, Wood LD, Silvestris N, Salvia R, Scarpa A, Luchini C. Prognostic Role of High-Grade Tumor Budding in Pancreatic Ductal Adenocarcinoma: A Systematic Review and Meta-Analysis with a Focus on Epithelial to Mesenchymal Transition. Cancers (Basel). 2019; 11. https://doi.org/10.3390/cancers 11010113 . [PubMed]

23. Collisson EA, Sadanandam A, Olson P, Gibb WJ, Truitt M, Gu S, Cooc J, Weinkle J, Kim GE, Jakkula L, Feiler HS, Ko AH, Olshen AB, et al. Subtypes of pancreatic ductal adenocarcinoma and their differing responses to therapy. Nat Med. 2011; 17:500-03. https://doi.org/10.1038/ nm.2344. [PubMed]

24. Waddell N, Pajic M, Patch AM, Chang DK, Kassahn KS, Bailey P, Johns AL, Miller D, Nones K, Quek K, Quinn MC, Robertson AJ, Fadlullah MZ, et al, and Australian Pancreatic Cancer Genome Initiative. Whole genomes redefine the mutational landscape of pancreatic cancer. Nature. 2015; 518:495-501. https://doi.org/10.1038/ nature14169. [PubMed]

25. Moffitt RA, Marayati R, Flate EL, Volmar KE, Loeza SG, Hoadley KA, Rashid NU, Williams LA, Eaton SC, Chung AH, Smyla JK, Anderson JM, Kim HJ, et al. Virtual microdissection identifies distinct tumor- and stromaspecific subtypes of pancreatic ductal adenocarcinoma. Nat Genet. 2015; 47:1168-78. https://doi.org/10.1038/ng.3398. [PubMed]

26. Biankin AV, Waddell N, Kassahn KS, Gingras MC, Muthuswamy LB, Johns AL, Miller DK, Wilson PJ, Patch AM, Wu J, Chang DK, Cowley MJ, Gardiner BB, et al, and Australian Pancreatic Cancer Genome Initiative. Pancreatic cancer genomes reveal aberrations in axon guidance pathway genes. Nature. 2012; 491:399-405. https://doi.org/10.1038/nature11547. [PubMed] 
27. Harada T, Chelala C, Bhakta V, Chaplin T, Caulee K, Baril P, Young BD, Lemoine NR. Genome-wide DNA copy number analysis in pancreatic cancer using high-density single nucleotide polymorphism arrays. Oncogene. 2008; 27:195160. https://doi.org/10.1038/sj.onc.1210832. [PubMed]

28. Aung KL, Fischer SE, Denroche RE, Jang GH, Dodd A, Creighton S, Southwood B, Liang SB, Chadwick D, Zhang A, O'Kane GM, Albaba H, Moura S, et al. GenomicsDriven Precision Medicine for Advanced Pancreatic Cancer: Early Results from the COMPASS Trial. Clin Cancer Res. 2018; 24:1344-54. https://doi.org/10.1158/1078-0432.CCR17-2994. [PubMed]

29. Connor AA, Denroche RE, Jang GH, Timms L, Kalimuthu SN, Selander I, McPherson T, Wilson GW, ChanSeng-Yue MA, Borozan I, Ferretti V, Grant RC, Lungu IM, et al. Association of Distinct Mutational Signatures With Correlates of Increased Immune Activity in Pancreatic Ductal Adenocarcinoma. JAMA Oncol. 2017; 3:774-83. https://doi.org/10.1001/jamaoncol.2016.3916. [PubMed]

30. Humphris JL, Patch AM, Nones K, Bailey PJ, Johns AL, McKay S, Chang DK, Miller DK, Pajic M, Kassahn KS, Quinn MC, Bruxner TJ, Christ AN, et al, and Australian Pancreatic Cancer Genome Initiative. Hypermutation In Pancreatic Cancer. Gastroenterology. 2017; 152:68-74.e2. https://doi.org/10.1053/j.gastro.2016.09.060. [PubMed]

31. Lupinacci RM, Goloudina A, Buhard O, Bachet JB, Maréchal R, Demetter $\mathrm{P}$, Cros J, Bardier-Dupas A, Collura A, Cervera P, Scriva A, Dumont S, Hammel P, et al. Prevalence of Microsatellite Instability in Intraductal Papillary Mucinous Neoplasms of the Pancreas. Gastroenterology. 2018; 154:1061-65. https://doi. org/10.1053/j.gastro.2017.11.009. [PubMed]

32. Hu ZI, Shia J, Stadler ZK, Varghese AM, Capanu M, SaloMullen E, Lowery MA, Diaz LA Jr, Mandelker D, Yu KH, Zervoudakis A, Kelsen DP, Iacobuzio-Donahue CA, et al. Evaluating Mismatch Repair Deficiency in Pancreatic Adenocarcinoma: Challenges and Recommendations. Clin Cancer Res. 2018; 24:1326-36. https://doi. org/10.1158/1078-0432.CCR-17-3099. [PubMed]

33. Kim ST, Klempner SJ, Park SH, Park JO, Park YS, Lim HY, Kang WK, Kim KM, Lee J. Correlating programmed death ligand 1 (PD-L1) expression, mismatch repair deficiency, and outcomes across tumor types: implications for immunotherapy. Oncotarget. 2017; 8:77415-23. https://doi. org/10.18632/oncotarget.20492. [PubMed]

34. Eatrides JM, Coppola D, Al Diffalha S, Kim RD, Springett GM, Mahipal A. Microsatellite instability in pancreatic cancer. J Clin Oncol. 2017; 34:e15753-e15753. https://doi.org/10.1200/JCO.2016.34.15_suppl.e15753.

35. Liu W, Shia J, Gönen M, Lowery MA, O’Reilly EM, Klimstra DS. DNA mismatch repair abnormalities in acinar cell carcinoma of the pancreas: frequency and clinical significance. Pancreas. 2014; 43:1264-70. https://doi. org/10.1097/MPA.0000000000000190. [ [
36. Yamamoto H, Itoh F, Nakamura H, Fukushima H, Sasaki S, Perucho M, Imai K. Genetic and clinical features of human pancreatic ductal adenocarcinomas with widespread microsatellite instability. Cancer Res. 2001; 61:3139-44. [PubMed]

37. Riazy M, Kalloger SE, Sheffield BS, Peixoto RD, Li-Chang HH, Scudamore CH, Renouf DJ, Schaeffer DF. Mismatch repair status may predict response to adjuvant chemotherapy in resectable pancreatic ductal adenocarcinoma. Mod Pathol. 2015; 28:1383-89. https:// doi.org/10.1038/modpathol.2015.89. [PubMed]

38. Le DT, Uram JN, Wang H, Bartlett BR, Kemberling H, Eyring AD, Skora AD, Luber BS, Azad NS, Laheru D, Biedrzycki B, Donehower RC, Zaheer A, et al. PD-1 Blockade in Tumors with Mismatch-Repair Deficiency. N Engl J Med. 2015; 372:2509-20. https://doi.org/10.1056/ NEJMoa1500596. [PubMed]

39. Le DT, Durham JN, Smith KN, Wang H, Bartlett BR, Aulakh LK, Lu S, Kemberling H, Wilt C, Luber BS, Wong F, Azad NS, Rucki AA, et al. Mismatch repair deficiency predicts response of solid tumors to PD-1 blockade. Science. 2017; 357:409-13. https://doi. org/10.1126/science.aan6733. [PubMed]

40. Lu H, Niu F, Liu F, Gao J, Sun Y, Zhao X. Elevated glypican-1 expression is associated with an unfavorable prognosis in pancreatic ductal adenocarcinoma. Cancer Med. 2017; 6:1181-91. https://doi.org/10.1002/cam4.1064. [PubMed]

41. Zhou CY, Dong YP, Sun X, Sui X, Zhu H, Zhao YQ, Zhang YY, Mason C, Zhu Q, Han SX. High levels of serum glypican-1 indicate poor prognosis in pancreatic ductal adenocarcinoma. Cancer Med. 2018; 7:5525-33. https:// doi.org/10.1002/cam4.1833. [PubMed]

42. Lai X, Wang M, McElyea SD, Sherman S, House M, Korc M. A microRNA signature in circulating exosomes is superior to exosomal glypican-1 levels for diagnosing pancreatic cancer. Cancer Lett. 2017; 393:86-93. https:// doi.org/10.1016/j.canlet.2017.02.019. [PubMed]

43. Bartel DP. MicroRNAs: target recognition and regulatory functions. Cell. 2009; 136:215-33. https://doi.org/10.1016/j. cell.2009.01.002. [PubMed]

44. Fu XL, Liu DJ, Yan TT, Yang JY, Yang MW, Li J, Huo YM, Liu W, Zhang JF, Hong J, Hua R, Chen HY, Sun YW. Analysis of long non-coding RNA expression profiles in pancreatic ductal adenocarcinoma. Sci Rep. 2016; 6:33535. https://doi.org/10.1038/srep33535. [PubMed]

45. López-Urrutia E, Bustamante Montes LP, Ladrón de Guevara Cervantes D, Pérez-Plasencia C, Campos-Parra AD. Crosstalk Between Long Non-coding RNAs, Micro-RNAs and mRNAs: Deciphering Molecular Mechanisms of Master Regulators in Cancer. Front Oncol. 2019; 9:669. https://doi. org/10.3389/fonc.2019.00669. [PubMed]

46. Giovannetti E, Funel N, Peters GJ, Del Chiaro M, Erozenci LA, Vasile E, Leon LG, Pollina LE, Groen A, Falcone A, Danesi R, Campani D, Verheul HM, Boggi U. 
MicroRNA-21 in pancreatic cancer: correlation with clinical outcome and pharmacologic aspects underlying its role in the modulation of gemcitabine activity. Cancer Res. 2010; 70:4528-38. https://doi.org/10.1158/0008-5472. CAN-09-4467. [PubMed]

47. Karasek P, Gablo N, Hlavsa J, Kiss I, VychytilovaFaltejskova P, Hermanova M, Kala Z, Slaby O, Prochazka V. Pre-operative Plasma miR-21-5p Is a Sensitive Biomarker and Independent Prognostic Factor in Patients with Pancreatic Ductal Adenocarcinoma Undergoing Surgical Resection. Cancer Genomics Proteomics. 2018; 15:321-27. https://doi.org/10.21873/cgp.20090. [PubMed]

48. Mikamori M, Yamada D, Eguchi H, Hasegawa S, Kishimoto T, Tomimaru Y, Asaoka T, Noda T, Wada H, Kawamoto K, Gotoh K, Takeda Y, Tanemura M, et al. MicroRNA-155 Controls Exosome Synthesis and Promotes Gemcitabine Resistance in Pancreatic Ductal Adenocarcinoma. Sci Rep. 2017; 7:42339. https://doi. org/10.1038/srep42339. [PubMed]

49. Kawaguchi T, Komatsu S, Ichikawa D, Morimura R, Tsujiura M, Konishi H, Takeshita H, Nagata H, Arita T, Hirajima S, Shiozaki A, Ikoma H, Okamoto K, et al. Clinical impact of circulating miR-221 in plasma of patients with pancreatic cancer. Br J Cancer. 2013; 108:361-69. https://doi.org/10.1038/bjc.2012.546. [PubMed]

50. Korpal M, Lee ES, Hu G, Kang Y. The miR-200 family inhibits epithelial-mesenchymal transition and cancer cell migration by direct targeting of E-cadherin transcriptional repressors ZEB1 and ZEB2. J Biol Chem. 2008; 283:14910-14. https://doi.org/10.1074/jbc.C800074200. [PubMed]

51. Yu Y, Feng X, Cang S. A two-microRNA signature as a diagnostic and prognostic marker of pancreatic adenocarcinoma. Cancer Manag Res. 2018; 10:1507-15. https://doi.org/10.2147/CMAR.S158712. [PubMed]

52. Shi XH, Li X, Zhang H, He RZ, Zhao Y, Zhou M, Pan ST, Zhao CL, Feng YC, Wang M, Guo XJ, Qin RY. A FivemicroRNA Signature for Survival Prognosis in Pancreatic Adenocarcinoma based on TCGA Data. Sci Rep. 2018; 8:7638. $\quad$ https://doi.org/10.1038/s41598-018-22493-5. [PubMed]

53. Liao $\mathrm{X}$, Han $\mathrm{C}$, Wang $\mathrm{X}$, Huang $\mathrm{K}$, Yu $\mathrm{T}$, Yang $\mathrm{C}$, Huang R, Liu Z, Han Q, Peng T. Prognostic value of minichromosome maintenance mRNA expression in early-stage pancreatic ductal adenocarcinoma patients after pancreaticoduodenectomy. Cancer Manag Res. 2018; 10:3255-71. https://doi.org/10.2147/CMAR.S171293. [PubMed]

54. Li L, Chen H, Gao Y, Wang YW, Zhang GQ, Pan SH, Ji L, Kong R, Wang G, Jia YH, Bai XW, Sun B. Long Noncoding RNA MALAT1 Promotes Aggressive Pancreatic Cancer Proliferation and Metastasis via the Stimulation of Autophagy. Mol Cancer Ther. 2016; 15:2232-43. https:// doi.org/10.1158/1535-7163.MCT-16-0008. [ [PubMed]
55. Pang EJ, Yang R, Fu XB, Liu YF. Overexpression of long non-coding RNA MALAT1 is correlated with clinical progression and unfavorable prognosis in pancreatic cancer. Tumour Biol. 2015; 36:2403-07. https://doi.org/10.1007/ s13277-014-2850-8. [PubMed]

56. Liu JH, Chen G, Dang YW, Li CJ, Luo DZ. Expression and prognostic significance of IncRNA MALAT1 in pancreatic cancer tissues. Asian Pac J Cancer Prev. 2014; 15:2971-77. https://doi.org/10.7314/APJCP.2014.15.7.2971. [PubMed]

57. Ye Y, Chen J, Zhou Y, Fu Z, Zhou Q, Wang Y, Gao W, Zheng S, Zhao X, Chen T, Chen R. High expression of AFAP1-AS1 is associated with poor survival and short-term recurrence in pancreatic ductal adenocarcinoma. J Transl Med. 2015; 13:137. https://doi.org/10.1186/s12967-0150490-4. [PubMed]

58. Song JY, Chen MQ, Guo JH, Lian SF, Xu BH. Combined pretreatment serum CA19-9 and neutrophil-to-lymphocyte ratio as a potential prognostic factor in metastatic pancreatic cancer patients. Medicine (Baltimore). 2018; 97:e9707. https://doi.org/10.1097/MD.0000000000009707. [PubMed]

59. Yu J, Wu WK, Li X, He J, Li XX, Ng SS, Yu C, Gao Z, Yang J, Li M, Wang Q, Liang Q, Pan Y, et al. Novel recurrently mutated genes and a prognostic mutation signature in colorectal cancer. Gut. 2015; 64:636-45. https://doi.org/10.1136/gutjnl-2013-306620. [PubMed]

60. Zhang H, Zhu M, Du Y, Zhang H, Zhang Q, Liu Q, Huang Z, Zhang L, Li H, Xu L, Zhou X, Zhu W, Shu Y, Liu P. A Panel of 12-lncRNA Signature Predicts Survival of Pancreatic Adenocarcinoma. J Cancer. 2019; 10:1550-59. https://doi.org/10.7150/jca.27823. [PubMed]

61. Wang W, Lou W, Ding B, Yang B, Lu H, Kong Q, Fan W. A novel mRNA-miRNA-lncRNA competing endogenous RNA triple sub-network associated with prognosis of pancreatic cancer. Aging (Albany NY). 2019; 11:2610-27. https://doi.org/10.18632/aging.101933. [PubMed]

62. Zhuo M, Yuan C, Han T, Cui J, Jiao F, Wang L. A novel feedback loop between high MALAT-1 and low miR$200 c-3$ p promotes cell migration and invasion in pancreatic ductal adenocarcinoma and is predictive of poor prognosis. BMC Cancer. 2018; 18:1032. https://doi.org/10.1186/ s12885-018-4954-9. [PubMed]

63. Meijer LL, Garajová I, Caparello C, Le Large TY, Frampton AE, Vasile E, Funel N, Kazemier G, Giovannetti E. Plasma miR-181a-5p Downregulation Predicts Response and Improved Survival After FOLFIRINOX in Pancreatic Ductal Adenocarcinoma. Ann Surg. 2018 Dec 9. https:// doi.org/10.1097/SLA.0000000000003084. [Epub ahead of print]. [PubMed]

64. Alix-Panabières C, Pantel K. Clinical Applications of Circulating Tumor Cells and Circulating Tumor DNA as Liquid Biopsy. Cancer Discov. 2016; 6:479-91. https://doi. org/10.1158/2159-8290.CD-15-1483. [PubMed]

65. Cheng H, Liu C, Jiang J, Luo G, Lu Y, Jin K, Guo M, Zhang Z, Xu J, Liu L, Ni Q, Yu X. Analysis of ctDNA to predict prognosis and monitor treatment responses in 
metastatic pancreatic cancer patients. Int J Cancer. 2017; 140:2344-50. https://doi.org/10.1002/ijc.30650. [PubMed]

66. Loft M, Lee B, Tie J, Gibbs P. Clinical Applications of Circulating Tumour DNA in Pancreatic Adenocarcinoma. J Pers Med. 2019; 9. https://doi.org/10.3390/jpm9030037. [PubMed]

67. Hadano N, Murakami Y, Uemura K, Hashimoto Y, Kondo N, Nakagawa N, Sueda T, Hiyama E. Prognostic value of circulating tumour DNA in patients undergoing curative resection for pancreatic cancer. Br J Cancer. 2016; 115:59-65. https://doi.org/10.1038/bjc.2016.175. [PubMed]

68. Earl J, Garcia-Nieto S, Martinez-Avila JC, Montans J, Sanjuanbenito A, Rodríguez-Garrote M, Lisa E, Mendía E, Lobo E, Malats N, Carrato A, Guillen-Ponce C. Circulating tumor cells (Ctc) and kras mutant circulating free Dna (cfdna) detection in peripheral blood as biomarkers in patients diagnosed with exocrine pancreatic cancer. BMC Cancer. 2015; 15:797. https://doi.org/10.1186/s12885-0151779-7. [PubMed]

69. Strijker M, Soer EC, de Pastena M, Creemers A, Balduzzi A, Beagan JJ, Busch OR, van Delden OM, Halfwerk H, van Hooft JE, van Lienden KP, Marchegiani G, Meijer SL, et al. Circulating tumor DNA quantity is related to tumor volume and both predict survival in metastatic pancreatic ductal adenocarcinoma. Int J Cancer. 2020; 146:1445-1456. https://doi.org/10.1002/ijc.32586. [PubMed]

70. Creemers A, Krausz S, Strijker M, van der Wel MJ, Soer EC, Reinten RJ, Besselink MG, Wilmink JW, van de Vijver MJ, van Noesel CJ, Verheij J, Meijer SL, Dijk F, et al. Clinical value of ctDNA in upper-GI cancers: A systematic review and meta-analysis. Biochim Biophys Acta Rev Cancer. 2017; 1868:394-403. https://doi.org/10.1016/j. bbcan.2017.08.002. [PubMed]

71. Ferreira MM, Ramani VC, Jeffrey SS. Circulating tumor cell technologies. Mol Oncol. 2016; 10:374-94. https://doi. org/10.1016/j.molonc.2016.01.007. [PubMed]

72. Bissolati M, Sandri MT, Burtulo G, Zorzino L, Balzano G, Braga M. Portal vein-circulating tumor cells predict liver metastases in patients with resectable pancreatic cancer. Tumour Biol. 2015; 36:991-96. https://doi.org/10.1007/ s13277-014-2716-0. [PubMed]

73. Gasparini-Junior JL, Fanelli MF, Abdallah EA, Chinen LT. Evaluating MMP-2 and TGFß-RI expression in circulating tumor cells of pancreatic cancer patients and their correlation with clinical evolution. Arq Bras Cir Dig. 2019; 32:e1433. https://doi.org/10.1590/0102672020190001e1433. [PubMed]

74. Zhou B, Xu JW, Cheng YG, Gao JY, Hu SY, Wang L, Zhan HX. Early detection of pancreatic cancer: Where are we now and where are we going? Int J Cancer. 2017; 141:231-41. https://doi.org/10.1002/ijc.30670. [PubMed]

75. Sun Y, Wu G, Cheng KS, Chen A, Neoh KH, Chen S, Tang Z, Lee PF, Dai M, Han RP. CTC phenotyping for a preoperative assessment of tumor metastasis and overall survival of pancreatic ductal adenocarcinoma patients.
EBioMedicine. 2019; 46:133-49. https://doi.org/10.1016/j. ebiom.2019.07.044. [PubMed]

76. Pleskow DK, Berger HJ, Gyves J, Allen E, McLean A, Podolsky DK. Evaluation of a serologic marker, CA19-9, in the diagnosis of pancreatic cancer. Ann Intern Med. 1989; 110:704-09. https://doi.org/10.7326/0003-4819-110-9-704. [PubMed]

77. Winter JM, Yeo CJ, Brody JR. Diagnostic, prognostic, and predictive biomarkers in pancreatic cancer. J Surg Oncol. 2013; 107:15-22. https://doi.org/10.1002/jso.23192. [PubMed]

78. Saad ED, Machado MC, Wajsbrot D, Abramoff R, Hoff PM, Tabacof J, Katz A, Simon SD, Gansl RC. Pretreatment CA 19-9 level as a prognostic factor in patients with advanced pancreatic cancer treated with gemcitabine. Int J Gastrointest Cancer. 2002; 32:35-41. https://doi. org/10.1385/IJGC:32:1:35. [PubMed]

79. Sezgin C, Karabulut B, Uslu R, Sanli UA, Goksel G, Yuzer Y, Goker E. Gemcitabine treatment in patients with inoperable locally advanced/metastatic pancreatic cancer and prognostic factors. Scand J Gastroenterol. 2005; 40:1486-92. https://doi.org/10.1080/00365520510023819. [PubMed]

80. Park JK, Yoon YB, Kim YT, Ryu JK, Yoon WJ, Lee SH. Survival and prognostic factors of unresectable pancreatic cancer. J Clin Gastroenterol. 2008; 42:86-91. https://doi. org/10.1097/01.mcg.0000225657.30803.9d. [PubMed]

81. Fernández A, Salgado M, García A, Buxò E, Vera R, Adeva J, Jiménez-Fonseca P, Quintero G, Llorca C, Cañabate M, López LJ, Muñoz A, Ramírez P, et al. Prognostic factors for survival with nab-paclitaxel plus gemcitabine in metastatic pancreatic cancer in real-life practice: the ANICE-PaC study. BMC Cancer. 2018; 18:1185. https://doi.org/10.1186/ s12885-018-5101-3. [PubMed]

82. Barhli A, Cros J, Bartholin L, Neuzillet C. Prognostic stratification of resected pancreatic ductal adenocarcinoma: Past, present, and future. Dig Liver Dis. 2018; 50:979-90. https://doi.org/10.1016/j.dld.2018.08.009. [PubMed]

83. Klapdor R, Bahlo M, Babinski A, Klapdor S. CA19-9 serum concentrations - analysis of the serum kinetics during firstline therapy of pancreatic cancer in relation to overall survival. Anticancer Res. 2010; 30:1869-74. [릴ed]

84. Glenn J, Steinberg WM, Kurtzman SH, Steinberg SM, Sindelar WF. Evaluation of the utility of a radioimmunoassay for serum CA 19-9 levels in patients before and after treatment of carcinoma of the pancreas. J Clin Oncol. 1988; 6:462-68. https://doi.org/10.1200/JCO.1988.6.3.462. [PubMed]

85. Halm U, Schumann T, Schiefke I, Witzigmann H, Mössner J, Keim V. Decrease of CA 19-9 during chemotherapy with gemcitabine predicts survival time in patients with advanced pancreatic cancer. Br J Cancer. 2000; 82:1013-16. https:// doi.org/10.1054/bjoc.1999.1035. [PubMed]

86. Ziske C, Schlie C, Gorschlüter M, Glasmacher A, Mey U, Strehl J, Sauerbruch T, Schmidt-Wolf IG. Prognostic value of CA 19-9 levels in patients with inoperable 
adenocarcinoma of the pancreas treated with gemcitabine. Br J Cancer. 2003; 89:1413-17. https://doi.org/10.1038/ sj.bjc.6601263. [PubMed]

87. Robert M, Jarlier M, Gourgou S, Desseigne F, Ychou M, Bouché O, Juzyna B, Conroy T, Bennouna J. Retrospective Analysis of CA19-9 Decrease in Patients with Metastatic Pancreatic Carcinoma Treated with FOLFIRINOX or Gemcitabine in a Randomized Phase III Study (ACCORD11/PRODIGE4). Oncology. 2017; 93:367-76. https://doi.org/10.1159/000477850. [PubMed]

88. Hess V, Glimelius B, Grawe P, Dietrich D, Bodoky G, Ruhstaller T, Bajetta E, Saletti P, Figer A, Scheithauer W, Herrmann R. CA 19-9 tumour-marker response to chemotherapy in patients with advanced pancreatic cancer enrolled in a randomised controlled trial. Lancet Oncol. 2008; 9:132-38. https://doi.org/10.1016/S14702045(08)70001-9. [PubMed]

89. Ko AH, Hwang J, Venook AP, Abbruzzese JL, Bergsland EK, Tempero MA. Serum CA19-9 response as a surrogate for clinical outcome in patients receiving fixeddose rate gemcitabine for advanced pancreatic cancer. Br J Cancer. 2005; 93:195-99. https://doi.org/10.1038/ sj.bjc.6602687. [PubMed]

90. Martin HL, Ohara K, Kiberu A, Van Hagen T, Davidson A, Khattak MA. Prognostic value of systemic inflammationbased markers in advanced pancreatic cancer. Intern Med J. 2014; 44:676-82. https://doi.org/10.1111/imj.12453. [PubMed]

91. Roxburgh CS, McMillan DC. Role of systemic inflammatory response in predicting survival in patients with primary operable cancer. Future Oncol. 2010; 6:149-63. https://doi. org/10.2217/fon.09.136. [PubMed]

92. Al Murri AM, Wilson C, Lannigan A, Doughty JC, Angerson WJ, McArdle CS, McMillan DC. Evaluation of the relationship between the systemic inflammatory response and cancer-specific survival in patients with primary operable breast cancer. Br J Cancer. 2007; 96:89195. https://doi.org/10.1038/sj.bjc.6603682. [PubMed]

93. Xiao WK, Chen D, Li SQ, Fu SJ, Peng BG, Liang LJ. Prognostic significance of neutrophil-lymphocyte ratio in hepatocellular carcinoma: a meta-analysis. BMC Cancer. 2014; 14:117. https://doi.org/10.1186/1471-2407-14-117. [PubMed]

94. Dell'Aquila E, Cremolini C, Zeppola T, Lonardi S, Bergamo F, Masi G, Stellato M, Marmorino F, Schirripa M, Urbano F, Ronzoni M, Tomasello G, Zaniboni A, et al. Prognostic and predictive role of neutrophil/lymphocytes ratio in metastatic colorectal cancer: a retrospective analysis of the TRIBE study by GONO. Ann Oncol. 2018; 29:924-30. https://doi.org/10.1093/annonc/mdy004. [PubMed]

95. Wang DS, Luo HY, Qiu MZ, Wang ZQ, Zhang DS, Wang FH, Li YH, Xu RH. Comparison of the prognostic values of various inflammation based factors in patients with pancreatic cancer. Med Oncol. 2012; 29:3092-100. https://doi.org/10.1007/s12032-012-0226-8. [PubMed]
96. Stotz M, Gerger A, Eisner F, Szkandera J, Loibner H, Ress AL, Kornprat P, AlZoughbi W, Seggewies FS, Lackner C, Stojakovic T, Samonigg H, Hoefler G, Pichler M. Increased neutrophil-lymphocyte ratio is a poor prognostic factor in patients with primary operable and inoperable pancreatic cancer. Br J Cancer. 2013; 109:41621. https://doi.org/10.1038/bjc.2013.332. [PubMed]

97. Liu Z, Jin K, Guo M, Long J, Liu L, Liu C, Xu J, Ni Q, Luo G, Yu X. Prognostic Value of the CRP/Alb Ratio, a Novel Inflammation-Based Score in Pancreatic Cancer. Ann Surg Oncol. 2017; 24:561-68. https://doi.org/10.1245/ s10434-016-5579-3. [PubMed]

98. Yamada Y, Fujii H, Watanabe D, Kato-Hayashi H, Ohata K, Kobayashi R, Ishihara T, Uemura S, Iwashita T, Shimizu M, Suzuki A. Severe Neutropenia is Associated with Better Clinical Outcomes in Patients with Advanced Pancreatic Cancer Who Receive Modified FOLFIRINOX Therapy. Cancers (Basel). 2018; 10. https://doi.org/10.3390/ cancers 10110454. [PubMed]

99. Chen Y, Shi Y, Yan H, Wang YR, Dai GH. Timing of chemotherapy-induced neutropenia: the prognostic factor in advanced pancreatic cancer patients treated with gemcitabine/ gemcitabine-based chemotherapy. Oncotarget. 2017; 8:66593-600. https://doi.org/10.18632/oncotarget.16980. [PubMed]

100. Yu SL, Xu LT, Qi Q, Geng YW, Chen H, Meng ZQ, Wang P, Chen Z. Serum lactate dehydrogenase predicts prognosis and correlates with systemic inflammatory response in patients with advanced pancreatic cancer after gemcitabinebased chemotherapy. Sci Rep. 2017; 7:45194. https://doi. org/10.1038/srep45194. [PubMed]

101. Adams MJ, Buehner M, Chandrasekhar K, Ford GC, Hackert ML, Liljas A, Rossmann MG, Smiley IE, Allison WS, Everse J, Kaplan NO, Taylor SS. Structurefunction relationships in lactate dehydrogenase. Proc Natl Acad Sci U S A. 1973; 70:1968-72. https://doi.org/10.1073/ pnas.70.7.1968. [PubMed]

102. Tas F, Aykan F, Alici S, Kaytan E, Aydiner A, Topuz E. Prognostic factors in pancreatic carcinoma: serum LDH levels predict survival in metastatic disease. Am J Clin Oncol. 2001; 24:547-50. https://doi.org/10.1097/00000421200112000-00003. [PubMed]

103. Hwang I, Kang J, Ip HN, Jeong JH, Kim KP, Chang HM, Yoo C, Ryoo BY. Prognostic factors in patients with metastatic or recurrent pancreatic cancer treated with first-line nab-paclitaxel plus gemcitabine: implication of inflammationbased scores. Invest New Drugs. 2019; 37:584-90. https:// doi.org/10.1007/s10637-018-0681-y. [PubMed]

104. Roshani R, McCarthy F, Hagemann T. Inflammatory cytokines in human pancreatic cancer. Cancer Lett. 2014; 345:157-63. https://doi.org/10.1016/j.canlet.2013.07.014. [PubMed]

105. Ebrahimi B, Tucker SL, Li D, Abbruzzese JL, Kurzrock R. Cytokines in pancreatic carcinoma: correlation with 
phenotypic characteristics and prognosis. Cancer. 2004; 101:2727-36. https://doi.org/10.1002/cncr.20672. [PubMed]

106. Mitsunaga S, Ikeda M, Shimizu S, Ohno I, Furuse J, Inagaki M, Higashi S, Kato H, Terao K, Ochiai A. Serum levels of IL-6 and IL-1 $\beta$ can predict the efficacy of gemcitabine in patients with advanced pancreatic cancer. Br J Cancer. 2013; 108:2063-69. https://doi.org/10.1038/ bjc.2013.174. [PubMed]

107. Farren MR, Mace TA, Geyer S, Mikhail S, Wu C, Ciombor K, Tahiri S, Ahn D, Noonan AM, VillalonaCalero M, Bekaii-Saab T, Lesinski GB. Systemic Immune Activity Predicts Overall Survival in Treatment-Naïve Patients with Metastatic Pancreatic Cancer. Clin Cancer Res. 2016; 22:2565-74. https://doi.org/10.1158/1078-0432. CCR-15-1732. [PubMed]

108. Schlick K, Magnes T, Ratzinger L, Jaud B, Weiss L, Melchardt T, Greil R, Egle A. Novel models for prediction of benefit and toxicity with FOLFIRINOX treatment of pancreatic cancer using clinically available parameters. PLoS One. 2018; 13:e0206688. https://doi.org/10.1371/ journal.pone.0206688. [PubMed]

109. Miller J, Wells L, Nwulu U, Currow D, Johnson MJ, Skipworth RJE. Validated screening tools for the assessment of cachexia, sarcopenia, and malnutrition: a systematic review. Am J Clin Nutr. 2018; 108:1196-1208. https://doi. org/10.1093/ajen/nqy244. [PubMed]

110. Freckelton J, Croagh D, Holt DQ, Fox A, Wong R, Lee M, Moore GT. Body Composition Adjusted Dosing of Gemcitabine-Nab-Paclitaxel in Pancreatic Cancer Does Not Predict Toxicity Compared to Body Surface Area Dosing. Nutr Cancer. 2019; 71:624-28. https://doi.org/10.1080/016 35581.2018.1542011. [PubMed]

111. Choi MH, Oh SN, Lee IK, Oh ST, Won DD. Sarcopenia is negatively associated with long-term outcomes in locally advanced rectal cancer. J Cachexia Sarcopenia Muscle. 2018; 9:53-59. https://doi.org/10.1002/jcsm.12234. [PubMed]

112. Ozola Zalite I, Zykus R, Francisco Gonzalez M, Saygili F, Pukitis A, Gaujoux S, Charnley RM, Lyadov V. Influence of cachexia and sarcopenia on survival in pancreatic ductal adenocarcinoma: a systematic review. Pancreatology. 2015; 15:19-24. https://doi.org/10.1016/j.pan.2014.11.006. [PubMed]

113. von Bernstorff W, Voss M, Freichel S, Schmid A, Vogel I, Jöhnk C, Henne-Bruns D, Kremer B, Kalthoff H. Systemic and local immunosuppression in pancreatic cancer patients. Clin Cancer Res. 2001 (Suppl 3); 7:925s-32s. [PubMed]

114. Skelton RA, Javed A, Zheng L, He J. Overcoming the resistance of pancreatic cancer to immune checkpoint inhibitors. J Surg Oncol. 2017; 116:55-62. https://doi. org/10.1002/jso.24642. [PubMed]

115. Hamada T, Nakai Y, Yasunaga H, Isayama H, Matsui $H$, Takahara N, Sasaki T, Takagi K, Watanabe T, Yagioka H, Kogure H, Arizumi T, Yamamoto N, et al. Prognostic nomogram for nonresectable pancreatic cancer treated with gemcitabine-based chemotherapy. $\mathrm{Br} \mathrm{J}$ Cancer.
2014; 110:1943-49. https://doi.org/10.1038/bjc.2014.131. [PubMed]

116. Le N, Sund M, Vinci A, Beyer G, Ashan Javed M, Krug S, Neessee A, Schober M, and GEMS collaborating group of Pancreas 2000. Prognostic and predictive markers in pancreatic adenocarcinoma. Dig Liver Dis. 2016; 48:22330. https://doi.org/10.1016/j.dld.2015.11.001. [PubMed]

117. Brennan MF, Kattan MW, Klimstra D, Conlon K. Prognostic nomogram for patients undergoing resection for adenocarcinoma of the pancreas. Ann Surg. 2004; 240:29398. https://doi.org/10.1097/01.sla.0000133125.85489.07. [PubMed]

118. Vernerey D, Huguet F, Vienot A, Goldstein D, PagetBailly S, Van Laethem JL, Glimelius B, Artru P, Moore MJ, André T, Mineur L, Chibaudel B, Benetkiewicz M, et al. Prognostic nomogram and score to predict overall survival in locally advanced untreated pancreatic cancer (PROLAP). Br J Cancer. 2016; 115:281-89. https://doi.org/10.1038/ bjc.2016.212. [PubMed]

119. Kou T, Kanai M, Yamamoto M, Xue P, Mori Y, Kudo Y, Kurita A, Uza N, Kodama Y, Asada M, Kawaguchi M, Masui T, Mizumoto M, et al. Prognostic model for survival based on readily available pretreatment factors in patients with advanced pancreatic cancer receiving palliative chemotherapy. Int J Clin Oncol. 2016; 21:118-25. https:// doi.org/10.1007/s10147-015-0864-x. [PubMed]

120. Hang J, Wu L, Zhu L, Sun Z, Wang G, Pan J, Zheng S, $\mathrm{Xu} \mathrm{K}, \mathrm{Du}$ J, Jiang H. Prediction of overall survival for metastatic pancreatic cancer: development and validation of a prognostic nomogram with data from open clinical trial and real-world study. Cancer Med. 2018; 7:2974-84. https://doi.org/10.1002/cam4.1573. [PubMed]

121. Ohmine K, Kawaguchi K, Ohtsuki S, Motoi F, Ohtsuka H, Kamiie J, Abe T, Unno M, Terasaki T. Quantitative Targeted Proteomics of Pancreatic Cancer: Deoxycytidine Kinase Protein Level Correlates to Progression-Free Survival of Patients Receiving Gemcitabine Treatment. Mol Pharm. 2015; 12:3282-91. https://doi.org/10.1021/acs. molpharmaceut.5b00282. [PubMed]

122. Swartz MJ, Batra SK, Varshney GC, Hollingsworth MA, Yeo CJ, Cameron JL, Wilentz RE, Hruban RH, Argani P. MUC4 expression increases progressively in pancreatic intraepithelial neoplasia. Am J Clin Pathol. 2002; 117:79196. https://doi.org/10.1309/7Y7N-M1WM-R0YK-M2VA. [PubMed]

123. Skrypek N, Duchêne B, Hebbar M, Leteurtre E, van Seuningen I, Jonckheere N. The MUC4 mucin mediates gemcitabine resistance of human pancreatic cancer cells via the Concentrative Nucleoside Transporter family. Oncogene. 2013; 32:1714-23. https://doi.org/10.1038/ onc.2012.179. [PubMed]

124. Tian Q, Zhang J, Tan TM, Chan E, Duan W, Chan SY, Boelsterli UA, Ho PC, Yang H, Bian JS, Huang M, Zhu YZ, Xiong $\mathrm{W}$, et al. Human multidrug resistance associated protein 4 confers resistance to camptothecins. Pharm Res. 
2005; 22:1837-53. https://doi.org/10.1007/s11095-0057595-z. [PubMed]

125. Capello M, Lee M, Wang H, Babel I, Katz MH, Fleming JB, Maitra A, Wang H, Tian W, Taguchi A, Hanash SM. Carboxylesterase 2 as a Determinant of Response to Irinotecan and Neoadjuvant FOLFIRINOX Therapy in Pancreatic Ductal Adenocarcinoma. J Natl Cancer Inst. 2015; 107. https://doi.org/10.1093/jnci/djv132. [PubMed]

126. Strippoli A, Rossi S, Martini M, Basso M, D’Argento E, Schinzari G, Barile R, Cassano A, Barone C. ERCC1 expression affects outcome in metastatic pancreatic carcinoma treated with FOLFIRINOX: A single institution analysis. Oncotarget. 2016; 7:35159-68. https://doi. org/10.18632/oncotarget.9063. [PubMed]

127. Mancuso A, Sacchetta S, Saletti PC, Tronconi C, Milesi L, Garassino M, Martelli O, Leone A, Zivi A, Cerbone L, Recine F, Sollami R, Labianca R, et al. Clinical and molecular determinants of survival in pancreatic cancer patients treated with second-line chemotherapy: results of an Italian/Swiss multicenter survey. Anticancer Res. 2010; 30:4289-95. [PubMed]

128. Tezuka S, Ueno M, Kobayashi S, Morimoto M, Ohkawa S, Hirotani A, Tozuka Y, Moriya S, Nakamura Y, Miyagi Y, Sugimori M, Maeda S. Predictive value of ERCC1, ERCC2, ERCC4, and glutathione S-Transferase Pi expression for the efficacy and safety of FOLFIRINOX in patients with unresectable pancreatic cancer. Am J Cancer Res. 2018; 8:2096-105. [PubMed]

129. Muckenhuber A, Berger AK, Schlitter AM, Steiger K, Konukiewitz B, Trumpp A, Eils R, Werner J, Friess H, Esposito I, Klöppel G, Ceyhan GO, Jesinghaus M, et al. Pancreatic Ductal Adenocarcinoma Subtyping Using the Biomarkers Hepatocyte Nuclear Factor-1A and Cytokeratin-81 Correlates with Outcome and Treatment Response. Clin Cancer Res. 2018; 24:351-59. https://doi. org/10.1158/1078-0432.CCR-17-2180. [ubMed]

130. Giovannetti E, Del Tacca M, Mey V, Funel N, Nannizzi S, Ricci S, Orlandini C, Boggi U, Campani D, Del Chiaro M, Iannopollo M, Bevilacqua G, Mosca F, Danesi R. Transcription analysis of human equilibrative nucleoside transporter-1 predicts survival in pancreas cancer patients treated with gemcitabine. Cancer Res. 2006; 66:3928-35. https://doi.org/10.1158/0008-5472.CAN-05-4203. [PubMed]

131. Song WF, Wang L, Huang WY, Cai X, Cui JJ, Wang LW. MiR-21 upregulation induced by promoter zone histone acetylation is associated with chemoresistance to gemcitabine and enhanced malignancy of pancreatic cancer cells. Asian Pac J Cancer Prev. 2013; 14:7529-36. https:// doi.org/10.7314/APJCP.2013.14.12.7529. [PubMed]

132. Heining C, Horak P, Uhrig S, Codo PL, Klink B, Hutter B, Fröhlich M, Bonekamp D, Richter D, Steiger K, Penzel R, Endris V, Ehrenberg KR, et al. NRG1 Fusions in KRAS
Wild-Type Pancreatic Cancer. Cancer Discov. 2018; 8:1087-95. https://doi.org/10.1158/2159-8290.CD-18-0036. [PubMed]

133. Shimada $Y$, Kohno $T$, Ueno $H$, Ino $Y$, Hayashi $H$, Nakaoku T, Sakamoto Y, Kondo S, Morizane C, Shimada K, Okusaka T, Hiraoka N. An Oncogenic ALK Fusion and an RRAS Mutation in KRAS Mutation-Negative Pancreatic Ductal Adenocarcinoma. Oncologist. 2017; 22:158-64. https://doi.org/10.1634/theoncologist.2016-0194. [PubMed]

134. Ghiorzo P. Genetic predisposition to pancreatic cancer. World J Gastroenterol. 2014; 20:10778-89. https://doi. org/10.3748/wig.v20.i31.10778. [PubMed]

135. Holter S, Borgida A, Dodd A, Grant R, Semotiuk K, Hedley D, Dhani N, Narod S, Akbari M, Moore M, Gallinger S. Germline BRCA Mutations in a Large ClinicBased Cohort of Patients With Pancreatic Adenocarcinoma. J Clin Oncol. 2015; 33:3124-29. https://doi.org/10.1200/ JCO.2014.59.7401. [PubMed]

136. Walsh CS. Two decades beyond BRCA1/2: homologous recombination, hereditary cancer risk and a target for ovarian cancer therapy. Gynecol Oncol. 2015; 137:343-50. https://doi.org/10.1016/j.ygyno.2015.02.017. [PubMed]

137. O'Connor MJ. Targeting the DNA Damage Response in Cancer. Mol Cell. 2015; 60:547-60. https://doi. org/10.1016/j.molcel.2015.10.040. [PubMed]

138. Lowery MA, Kelsen DP, Stadler ZK, Yu KH, Janjigian YY, Ludwig E, D'Adamo DR, Salo-Mullen E, Robson ME, Allen PJ, Kurtz RC, O'Reilly EM. An emerging entity: pancreatic adenocarcinoma associated with a known BRCA mutation: clinical descriptors, treatment implications, and future directions. Oncologist. 2011; 16:1397-402. https:// doi.org/10.1634/theoncologist.2011-0185. [PubMed]

139. Cui Y, Brosnan JA, Blackford AL, Sur S, Hruban RH, Kinzler KW, Vogelstein B, Maitra A, Diaz LA Jr, Iacobuzio-Donahue CA, Eshleman JR. Genetically defined subsets of human pancreatic cancer show unique in vitro chemosensitivity. Clin Cancer Res. 2012; 18:6519-30. https://doi.org/10.1158/1078-0432.CCR-12-0827. [PubMed]

140. Golan T, Kanji ZS, Epelbaum R, Devaud N, Dagan E, Holter S, Aderka D, Paluch-Shimon S, Kaufman B, Gershoni-Baruch R, Hedley D, Moore MJ, Friedman E, Gallinger S. Overall survival and clinical characteristics of pancreatic cancer in BRCA mutation carriers. Br J Cancer. 2014; 111:1132-38. https://doi.org/10.1038/bjc.2014.418. [PubMed]

141. Golan T, Hammel P, Reni M, Van Cutsem E, Macarulla T, Hall MJ, Park JO, Hochhauser D, Arnold D, Oh DY, Reinacher-Schick A, Tortora G, Algül H, et al. Maintenance Olaparib for Germline BRCA-Mutated Metastatic Pancreatic Cancer. N Engl J Med. 2019; 381:317-27. https://doi.org/10.1056/NEJMoa1903387. [PubMed] 